\title{
8
}

\section{Odors Treatment: Biological Technologies}

\author{
Bram Sercu, João Peixoto, Kristof Demeestere, \\ Toon van Elst, and Herman Van Langenhove
}

\section{INTRODUCTION}

Physical-chemical waste gas cleaning techniques have proven their efficiency and reliability and will continue to occupy their niche, but several disadvantages remain. Among them are high investment and operation costs and the possible generation of secondary waste streams. With biological waste treatment techniques, reactor engineering is often less complicated and consequently costs are less. In addition, usually no secondary wastes are produced. Biological methods are nonhazardous and benign for the environment. Possible drawbacks are restricted knowledge about the biodegradation processes, limited process control, and relatively slow reaction kinetics. Anyway, the biological methods for the removal of odors and volatile organic compounds (VOCs) from waste gases are cost-effective technologies, when low concentrations (below $1-10 \mathrm{~g} / \mathrm{m}^{-3}$ ) are to be dealt with (Kosteltz et al., 1996). Therefore, decision making can be based merely on economical analysis. Like the treatment of liquid effluents, gaseous streams will be more often considered for biological treatment. For organic compounds, the biological reaction can be described as:

$$
\mathrm{CHO}+\mathrm{O}_{2}+\text { nutrients } \rightarrow \mathrm{C}_{5} \mathrm{H}_{7} \mathrm{O}_{2} \mathrm{~N} \text { (cell dry weight) }+\mathrm{CO}_{2}+\mathrm{H}_{2} \mathrm{O}+\text { heat }
$$

When heteroatoms are present (e.g., chlorine, sulfur), end-products like $\mathrm{HCl}$ or $\mathrm{H}_{2} \mathrm{SO}_{4}$ can be formed. For efficient pollutant removal, target pollutants have to be sufficiently biodegradable and bioavailable. A major advantage in the case of odor treatment is that biocatalysts have high affinity for the substrates, which

BRAM SERCU, JOÃO PEIXOTO, KRISTOF DEMEESTERE, TOON VAN ELST, AND HERMAN VAN LANGENHOVE • EnVOC Research Group, Department of Organic Chemistry, Faculty of Bioscience Engineering, Ghent University, 9000 Gent, Belgium. Department of Biological Engineering, CEB, University of Minho, 4710-057 Braga, Portugal. Project Research Gent nv, 9030 Gent, Belgium. 
allows efficient treatment of low influent concentrations. Biocatalysts also operate at room temperature and they have innocuous final products (e.g., carbon dioxide and water). Provided that you have the right inocula, microorganisms can metabolize almost every compound there is. In general, odors consist of a very complex mixture of volatile organic as well as inorganic compounds. The most relevant compounds regarding odors in the food industry are nitrogencontaining compounds (ammonia, amines, amides, and more complex molecules like indole and scatole), reduced sulfur compounds (hydrogen sulfide and volatile organic sulfur compounds) and VOCs like alcohols, aldehydes, volatile fatty acids, and phenols. Most are easily biodegradable.

\section{GENERAL OVERVIEW OF TECHNIQUES}

Several biological waste gas treatment reactor concepts exist. They can be distinguished according to their filter material (organic or inorganic) and the type of liquid phase (noncontinuous or continuous). Both characteristics influence mass transfer and the presence or type of biofilm. In most cases, pollutants are first transferred from the gas phase to the liquid phase and subsequently to the biofilm (Figure 1). It has been argued, however, that pollutants can directly be transferred from the gas phase to the biofilm when no water film is present, or that fungal mycelia, protruding in the gas phase, can directly take up substrates without a dissolution step (Engesser and Plaggemeier, 2000). Optimal conditions for the organisms (micro)environment should be provided. Temperature, $\mathrm{pH}$, water activity, nutrient availability, oxygen concentration, and osmotic potential are important parameters. In practice, most of these parameters can be controlled in an acceptable range by reactor choice, operation, and control. However, sometimes waste gas characteristics like high or fluctuating temperatures and low oxygen concentrations are more difficult to adjust, leading to limitations in the application area of biological waste gas treatment techniques.

Laboratory studies provide much information about the removal of single compounds or simple mixtures, but especially for VOCs, often relatively high

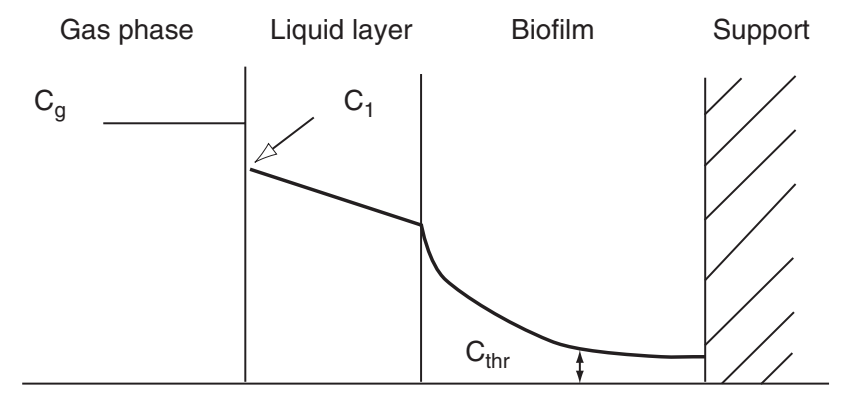

Figure 1. Pollutant transfer during biological waste gas cleaning (Waweru et al., 2000). 
influent concentrations are investigated, conditions not prevailing in odorous waste gases. Although the experimental conditions and the influent gas can be controlled carefully in lab studies, it is sometimes difficult to extrapolate results to real situations, especially when the composition of the waste gas is very complex or unknown.

Other studies investigate the removal of odors in full-scale installations or use pilot-scale waste gas treatment units receiving waste air from industrial plants. In this case, data with real complex odorous mixtures are obtained. However, only in a few cases the waste gas characteristics in two different plants are much alike. Therefore, before installing a biological waste gas treatment reactor, often a series of pilot-scale experiments is conducted on-site to investigate performance and design criteria. Devinny et al. (1999) recommended the following steps in a protocol for biofilter design and implementation: (1) preliminary investigations of the waste stream (e.g., pollutant concentrations, process flow rate, relative humidity, temperature), (2) literature research and modeling to determine if biofiltration is an appropriate technique, and (3) possibly further bench- and pilot-scale experiments to obtain a final reactor design.

Many classifications and denominations of bioreactors have been appearing in the literature. Here we shall classify them in five main groups: biofilters, biotrickling filters, biowashers, and two more recent techniques: the biological plate tower and the membrane bioreactor. Many associations of different reactors are also possible. Stability, adaptability, and low equipment and operational costs are the requests they all must meet.

\subsection{Biofilters}

Biofiltration is often used with a broader meaning, referring to all the waste air biological technologies. Strictly it means the most used technology about this matter: the biofilters. They made their appearance in the 1950s in the deodorization of air from wastewater treatment or composting plants. Nowadays they are aimed not only at air polluted with organic gases, such as VOCs and many other hydrocarbons, but also ammonia or $\mathrm{H}_{2} \mathrm{~S}$. They are more efficient with low molecular weight gases, with high solubility in water and simpler molecular bonds. Biofiltration has been extensively used, because waste gases in this case generally contain low concentrations of well biodegradable organic and inorganic compounds.

Basically, a biofilter is a layer of biologically active media (an organic filter matrix), usually of natural origin. The filter particles are typically soil, compost, peat, wood chips, tree bark, and heather. Granular activated carbon and plastic material are also used. One kind or several combinations of particles have been used. The media must provide a large surface area, nutrients and moisture (around $50 \%$ of the media) for the microbial activity, and adsorption/absorption of the odorous molecules. The microflora for the degradation of odors-mainly 
bacteria and fungi-is part of the package. There is no continuous water phase. For better results, the addition of nutrients containing nitrogen and phosphorus must be considered, although this will add some cost to the process. The presence of bulking inerts usually calls for the addition of nutrients, mainly with high load regimes (Devinny et al., 1999). Adequate porosity (around 0.50) is essential for low pressure drop (power requirements).

To build a conventional open-bed filter (Figure 2), in the early ages of the technique, a hole was excavated in the ground (around $1.0 \mathrm{~m}$ deep) and filled up with a bed of the selected media. Nowadays, synthetic material or concrete is used. Perforated piping or other systems are used for gas distribution under the bed. The waste air flow, combined with the void fraction, causes the residence time to be normally between 15 and $60 \mathrm{sec}$, the time it takes for the odors to be absorbed and metabolized through the filter. Surface loading rates are about $1.2 \mathrm{~m}^{3} \mathrm{~m}^{-2} \mathrm{~min}^{-1}$ (Devinny et al., 1999). Impermeableness is desirable to avoid liquid leaching.

For optimal long-term operation of biofilters, next to controlling the biofilter moisture content, precautions should be made to prevent acidification if sulfur or nitrogen-containing compounds are present. This can be accomplished by buffering, e.g., by adding $\mathrm{CaCO}_{3}$ (Rafson, 1998), or regular replacement of the filter material (every 1 to 5 years, depending on the loading rate). The latter treatment is also needed to remove other accumulated intermediates or end-products, to prevent high pressure drops, and to prevent nutrient limitation if nutrients are not provided during biofilter operation. Indeed, removal efficiencies go from $60 \%$ to $100 \%$, depending on the media and the pollutants contaminating the air. Initial performance is very good but as time goes on problems may occur, leading to severe degradation of efficiency. Clogging and channeling are likely to appear.

Modular closed systems are commercially available. They minimize the surface for installation because they are stacks of trays that can be set in series or parallel arrangements, or combinations of both. The usual time of operation, with good removal characteristics, for conventional systems (2 to

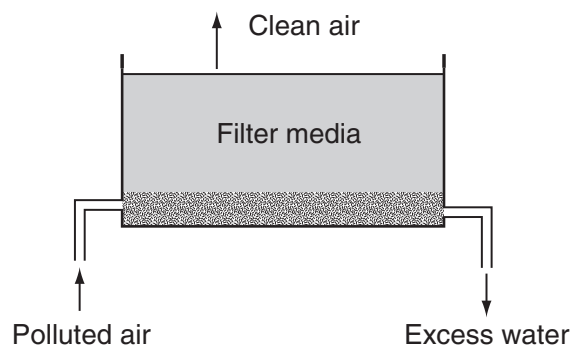

Figure 2. Schematic of a conventional open-bed biofilter. 
4 years, according to Devinny et al., 1999), is extended due to selected media, uniform distribution, and the inclusion of controls for temperature (usually around $37^{\circ} \mathrm{C}$ ), $\mathrm{pH}$, moisture, and airstream relative humidity (it must be near saturation).

\subsection{Biotrickling Filters}

Biotrickling filters are single unit operation reactors (for both capture and destruction), like biofilters. A packed column is inoculated with microorganisms that attach to the particles. Biofilms grow using nutrients supplied by the contaminated airstream and by a liquid flow that trickles down the packing, continuously or periodically. The liquid moving phase and the inorganic nature of the media particles are the most important differences between biofilters and biotrickling filters (Figure 3). Unlike biofilters that use natural materials, most particles for biotrickling filters are built with plastic, steel, or ceramic material. The simplest of all is the Raschig ring. Many particle designs have been used. The odor is first transferred from the air to the circulating water. Next it must diffuse to the biofilm. Finally the microorganisms oxidize the compounds.

In previous studies using a biotrickling filter for VOC removal with Pseudomonas putida as the biodegrading bacteria, several packing materials were checked to try to avoid channeling and clogging to block the process (Peixoto and Mota, 1998). It was proved that it is very difficult to overcome the mentioned problems, even when using 20-mm Raschig rings. The presence of the four phases (gas-vapor, liquid, biological, and solid) involved in the process

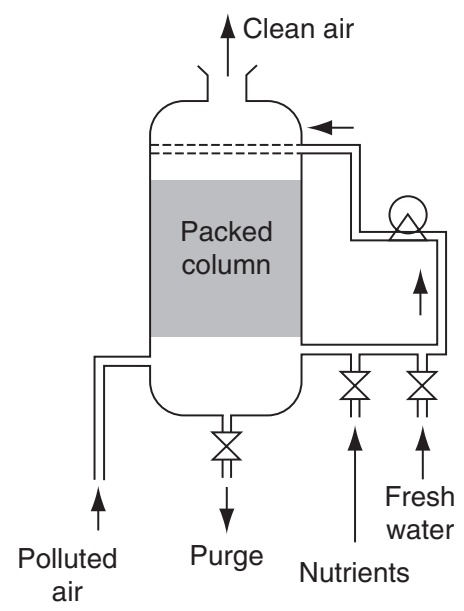

Figure 3. Schematic of a biotrickling filter. 
makes things very hard to deal with. Even with a high surface area and porosity, the bacterial growth reduced significantly those parameters in a short time. Ultimately the flow used only one last channel (Figure 4), with evident poor efficiency and higher pressure drop, and the process had to stop. Clogging is a direct result of the bacterial (fungal) growth. Growth means that the microorganisms are metabolizing the pollutants, as they are meant to. Therefore, it does not seem to make sense to try to limit the growth to avoid clogging and channeling. A way to remove the exceeding biomass seems to be the natural answer but very tough to find and a settling tank would be needed after the reactor. Backwashing and high shear stress do not seem to solve the problem.

\subsection{Biowashers}

In biowashers the biomass is suspended in the liquid phase. The waste content from the air is first washed and next oxidized by the suspended microorganisms. There may be one or two separate units for absorption and metabolization.

Classically, the airstream is washed in a spray chamber (scrubber; packed bed scrubber) and then the liquid phase is sent to an activated sludge tank, where the pollutants are oxidized (Figure 5).

Together, these two units form a bioreactor which is commonly named bioscrubber. Instead of the activated sludge tank, the contaminated liquid may be sent to an airlift reactor (Ritchie and Hill, 1995; Rittmann et al., 2000). This kind of reactor, also named circulating-bed biofilm reactor, is known for its good
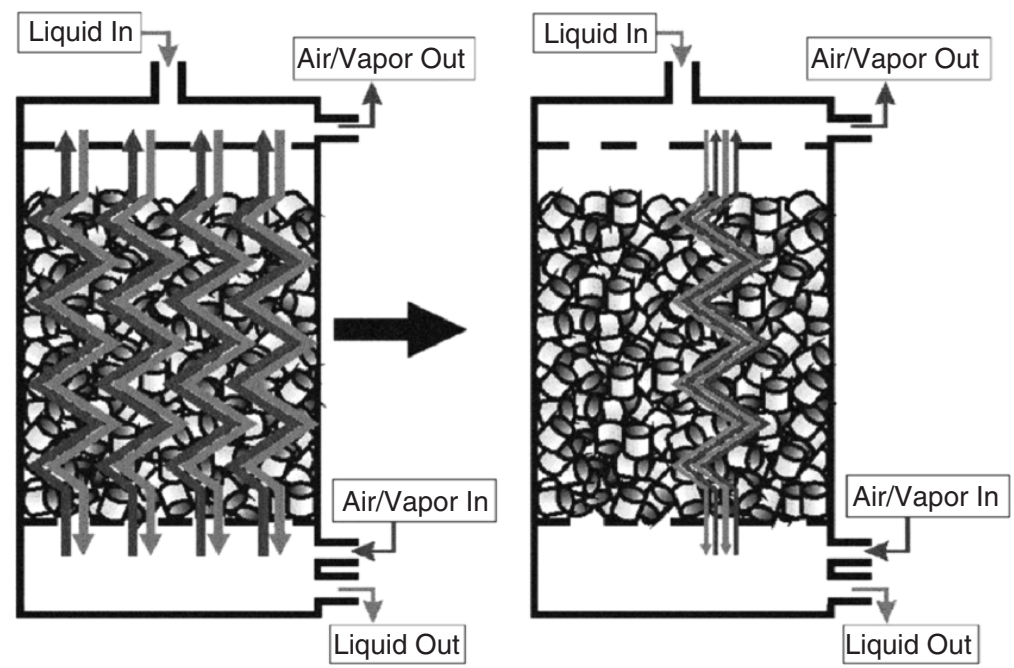

Figure 4. Evolution of a biotrickling filter packed with Raschig rings, after colonization by bacteria, due to clogging and chaneling. 


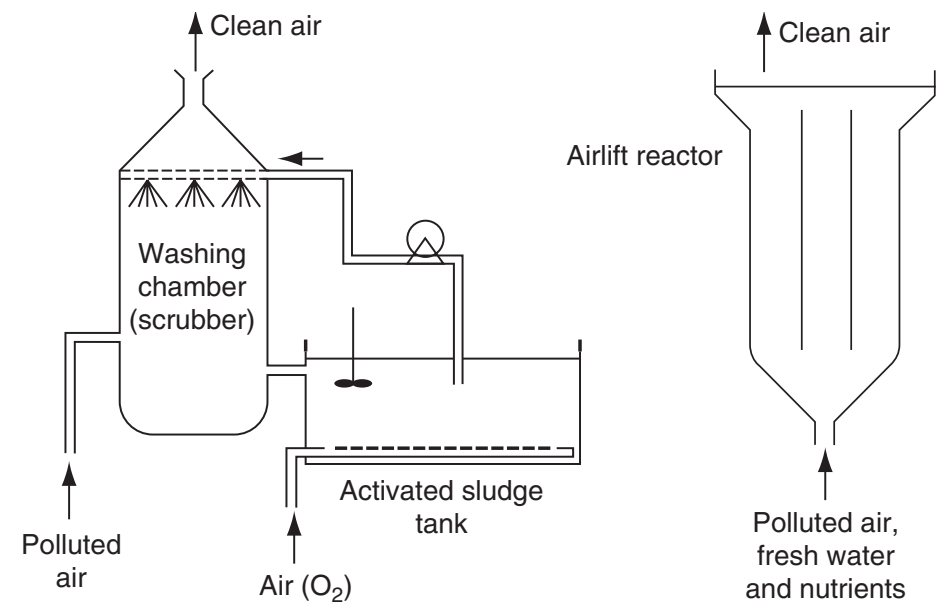

Figure 5. Schematic of biowashers: to the left, a two unit reactor with scrubber and activated sludge; to the right, a single unit airlift reactor.

mass transfer properties. Although the biomass in an airlift reactor is attached to particles, these are still suspended in the circulating liquid phase.

In a simpler way, absorption and oxidation may happen in a single unit operation. The airstream is directly bubbled to the liquid phase of the activated sludge tank or the airlift reactor (Figure 5), where regeneration takes place. In both cases, the air is washed and at the same time it supplies oxygen for the aerobic oxidation and mechanical power for the suspension and agitation of the particles/biomass in the bulk water. For this form of operation, the liquid phase never leaves the reactor, only being added to replace losses, due to evaporation and sludge purge. The air (or pure oxygen) for the oxygenation of the tank water is replaced by the polluted airstream. This simple solution, if fit, may be economically interesting.

Bioscrubbers are only sporadically used, mainly for removing high concentrations of highly water-soluble compounds. They have been used in the treatment of waste gases from incinerators and foundry industry (amines, phenol, formaldehyde, ammonia).

\subsection{Comparison of Technologies}

Table 1 summarizes the properties of the bioreactors described above and includes the biological plate tower (BPT). When the environmental conditions become toxic or aggressive, the biofilms play an important role in protecting the microorganisms in them. Therefore, attached biomass is less prone to inhibition and destruction. Besides, the growth rate may exceed the dilution rate without washing out the biomass. Biofilters, biotrickling filters, and airlift reactors, all grow attached biofilms. 
Table 1. Four entry characterization of biological systems for air pollution control

\begin{tabular}{|c|c|c|c|c|c|}
\hline & & \multicolumn{2}{|c|}{ LIQUID PHASE } & & \\
\hline & & Circulating & Stationary & & \\
\hline \multirow{2}{*}{$\begin{array}{l}\text { MicROBIAL } \\
\text { FLORA }\end{array}$} & Dispersed & Biowasher & & $\begin{array}{l}\text { Spray/ } \\
\text { shower }\end{array}$ & \multirow{2}{*}{ COLUMn TYPE } \\
\hline & Attached & $\begin{array}{l}\text { Biotrickling } \\
\text { filter; } B P T\end{array}$ & Biofilter & $\begin{array}{c}\text { Packing; } \\
\text { plates }\end{array}$ & \\
\hline & & $\begin{array}{l}\text { Supplied with } \\
\text { water }\end{array}$ & $\begin{array}{c}\text { Part of the } \\
\text { packing media }\end{array}$ & & \\
\hline & & MineRAI & UTRIENTS & & \\
\hline
\end{tabular}

Compact biofilters reduced significantly the footprint of conventional ones and have shortened the disadvantage related to the need of a huge application area. The absence of a moving liquid phase is its big disadvantage. For the control of the temperature, $\mathrm{pH}$, and dissolved oxygen, and the supply of nutrients, the presence of liquid water is a major advantage. One risk for open-bed biofilters is to get flooded by rain or dried out by the sun. Anyway, when the application area is not a problem, biofilters are still the most-used technology, due to the accumulated knowledge, their low cost, and simplicity to operate. One concern related to openbed biofilters is the release of microorganisms to the surrounding air. Food and fermentation industries need an environment with a controlled amount of microorganisms because of the nature of their processes. Van Groenestijn and Hesselink (1993) refer to emissions up to $10^{4}$ colony-forming units per cubic meter of treated gas. To minimize the risk to the process, an enclosed biofilter with an induced draft system (vacuum), as described in Devinny et al. (1999), should be preferred. This way only clean air will be drawn into the system if leaks are present. The final ventilation ducting must be positioned accordingly.

Biotrickling filters are used because of their ability for process control and are recommended when high concentrations of (acidifying) compounds have to be treated, or when only limited area space is available on site. Biowashers are favored when the pollutants have high solubility in water. Otherwise they are water-consuming and less attractive. If an existing activated sludge tank can receive the waste air from another process, that fact may be very profitable. It is necessary to guarantee that the new pollutants will not interfere with the activated sludge performance. Stripping of dissolved odors, flora inhibition, and filamentous bulking are some of the problems that may appear or get out of control.

Contacting times, application area, toxicity of pollutants, acid production during degradation, clogging, chaneling, solubility in water, adhesion to packings, costs of technology, one or several pollutants, selected species or natural consortia, pressure drop, selection of support media, open or closed-beds, and 
so on, are variables to be considered. With so many variables, there is still a long way to go before one can be sure of what solution is the best. For the same reason, modeling is also very difficult. For further information about reactor design and modeling, books of Devinny et al. (1999) and Kennes and Veiga (2001) are recommended.

\subsection{New Technologies}

\subsubsection{Biological Plate Tower (BPT)}

The big mistake in the transposition from physical-chemical to biological reactors is to forget that the presence of biofilms completely changes the behavior and performance of the reactor. Biofilm growth is chaotic and never tridimensionally homogeneous on a random packing. Oriented packing has better results but not yet good enough. A good physical-chemical reactor does not have to be a good biological one and it is indeed a poor option in many situations. Four-phase reactors always bring about hydrodynamic problems. Sloughing, channeling, and clogging always occur. A good efficiency of removal makes it happen faster. To solve these problems and make the process easy to operate steadily for a long time, a new concept of reactor was designed and tested with air polluted with VOCs. Pseudomonas putida was the selected inoculum. The effluent simulation was achieved with the mixing chamber described in Peixoto and Mota (1997).

The observation of the growth on the plane surfaces (top liquid distributor, base plate) of a biotrickling filter (Figure 6) suggested a design based on

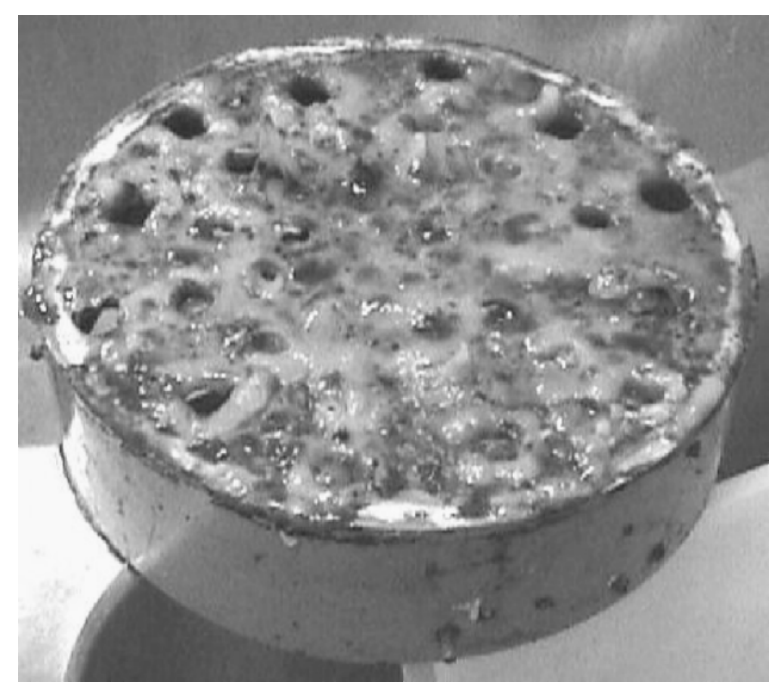

Figure 6. Liquid distributor showing the growth of biomass on the lower surface. On the top side, that occurrence was even stronger. 
horizontal surfaces. Basically, the BPT is a pile of parallel circular plates with a single hole on the border. The plates are placed in such a way that the holes will alternate $\left(180^{\circ}\right)$ from one to the next plate. In this way, a cascade of liquid will go downward, changing direction from plate to plate. The gaseous stream follows the opposite direction, upward. The bacteria attach to their top surface. Figure 7 shows the schematic of the flows and biofilm growth on the plates.

The reactor is a four-module (about $28.8 \mathrm{dm}^{3}$ each) BPT with 20 plates in each module. An individual plate surface area (top face) is about $40195 \mathrm{~mm}^{2}$. The scratched surfaces of the plates were intended to make the bacterial adhesion easier. Only two or three of the four modules are operated continuously. The other(s) is kept free and ready to replace any one that reaches saturation with biomass. In this way the operation can be kept going virtually forever.

The performance is quite stable (the biofilm activity, surface-dependent, is kept approximately constant) and the constant surface contact area makes it easy to model and scale-up the process. The total surface area and the space between plates can be designed for the desired operating time. In theory, the available surface in a BPT is a tenth of the surface in a biotrickling filter, considering the same total volume.

The new design proved to ensure a stable operation for longer periods, as well as high VOC removal (92\% removal for inlet toluene concentration of $10 \mathrm{~g} \mathrm{~m}^{-3}$ and empty bed residence time, EBRT $=108 \mathrm{sec}$ ). It has very good hydrodynamic performance and operates continuously without problem. In the long term, the short area is compensated by the steady operation.

The disposal of the newly formed biomass is also much easier than in the biotrickling filter. Unlike biofilters whose packing has to be rejected after a certain

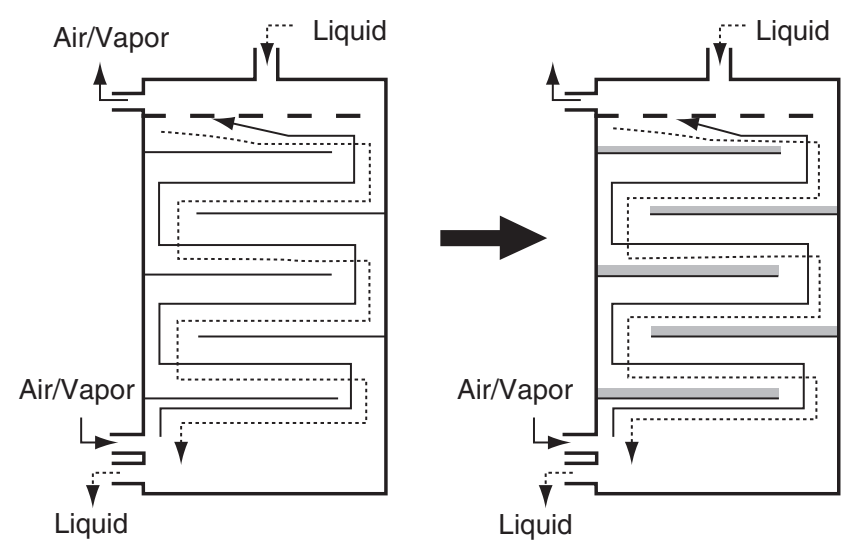

Figure 7. Simplified schematics of the BPT, with only five plates, to better visualize the directions of both flows and the attached biofilm on the upper surface of the plates. 
time of operation, BPT biomass is withdrawn as a water-rich solid phase - the biofilm attached to the plates - and quite easy to handle. When the thickness of the biofilm reaches the maximum value allowable, the set of plates is simply replaced by a clean one and the biomass is dealt with outside the reactor. Sampling the biofilm for analysis is very easy. It does not oblige the operation to be stopped, or severely shaken as it happens with biotrickling filters, and any plate can be sampled. Even operation demands a constant surface of biofilm. Oxygen uptake rate measurements were made to find out if there were great activity differences between different plates and between the surface and inside the biofim. The respiratory activity was similar (about $0.11 \mathrm{mg} \mathrm{g}^{-1} \mathrm{~s}^{-1}$, mass of oxygen per mass of volatile solids per time) for the superficial samples of all plates, showing some difference (up to about $20 \%$ ) for the lower ones where it was higher. The middle samples had almost zero activity $\left(0.01 \mathrm{mg} \mathrm{g}^{-1} \mathrm{~s}^{-1}\right.$ or less $)$ and none of the base samples showed any activity. For the respirometry tests, the carbon source was phenol. The plates at the bottom of each module had thicker biofilms than the upper ones, due to the higher concentration of the carbon source and oxygen in the entrance. The first module, which receives the higher dose, is the one that shows the thickest films, reaching over $15 \mathrm{~mm}$ until needing to be replaced (Figure 8).

The research on the BPT is still ongoing. Assays to quantify VOC and odor removals are now being planned. In the future, different bacteria, plate shapes, and distances between plates will be tested. The bacterial growth hanging from holes in the plates (sieve trays, similar to Figure 6) also will be investigated. The possibility of using different bacteria in different modules also will be considered.

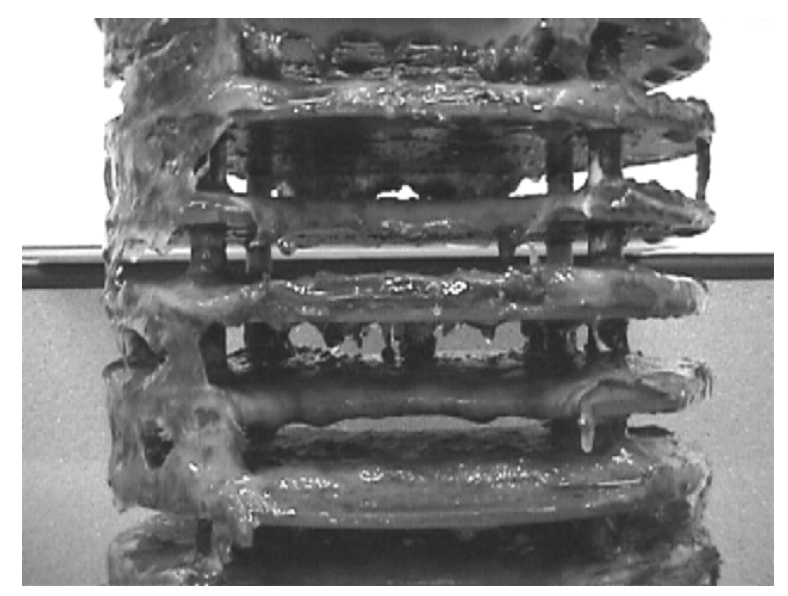

Figure 8. Photograph of the bottom plates of the first module showing the biofim growth on the BPT plates. The huge biofilm does not endanger the permeability of the system. 


\subsubsection{Membrane Bioreactor}

In the membrane bioreactor concept, one side of the membranes is dry and acts as a surface for uptake of pollutants from the air flowing along the membranes, while the other side is kept wet and covered by a biofilm. In Figure 9, a flat membrane bioreactor with a composite membrane is shown, but also other configurations like hollow fiber membranes modules can be applied. Pollutants diffuse through the membrane and are subsequently degraded by the microorganisms in the biofilm or in the recirculating aqueous phase. By continuous recirculation of the aqueous phase, the microbial degradation process can be easily controlled. The main advantages of membrane bioreactors for waste gas treatment include the high specific surface area, the ability to prevent clogging, the good reactor control, the physical separation of gas and biofilm, the low pressure drop, the absence of channeling, and the independent control of gas and liquid phase (De Bo, 2002). Potential disadvantages are the high investment costs, the additional mass transfer resistance caused by the membrane, a decreased biofilm activity as the biofilm ages, and clumping of hollow fiber membranes at high biofilm growth. The reactor concept, although not implemented in practice yet, has potential to eliminate VOCs characterized by poor water solubility, by lack of biodegradability, and by toxicity (Reij et al., 1998). Recently a flat membrane reactor was developed and applied for the degradation of DMS and toluene as single compounds (De Bo et al., 2002, 2003). In this case a composite membrane was used, guaranteeing a

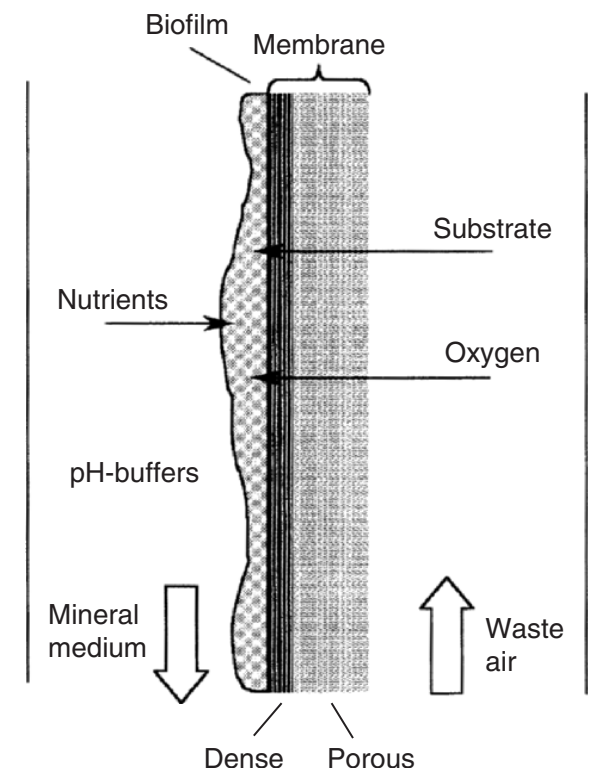

Figure 9. Scheme of a flat membrane bioreactor for waste gas treatment (De Bo, 2002). 
stable long-term reactor performance because clogging of the porous membrane was prevented. For DMS, an $\mathrm{EC}_{\max }$ of $4.8 \mathrm{~kg} \mathrm{~m}^{-3} \mathrm{~d}^{-1}$ was obtained, which was higher than any reported figure for biofilters or biotrickling filters.

\section{REMOVAL OF COMMON ODORS}

Most of the work has been done about removal of ammonia, reduced sulfur compounds (either single or as a mixture), and odorous VOCs, especially with biofiltration. About compounds like amides, indole, scatole, and pyridine no information was found. However, it can be assumed that when bioreactors can operate with high odor reduction efficiency, these compounds are also sufficiently degraded.

\subsection{Removal of Ammonia}

Within the group of odorous nitrogen-containing compounds, ammonia is by far the most investigated and documented compound with respect to its removal from waste gases by biological treatment technologies. Although ammonia has a rather high odor threshold value (3.9 ppmv to $5.8 \mathrm{ppmv}$ ) compared to many other odorous (nitrogen) compounds (Weckhuysen et al., 1994; Devos et al., 1990), and consequently dilutes rapidly to below detection downwind from the emission source, its very sharp and unpleasant odor can cause a severe odor nuisance nearby its emission source. Among biotechnological waste gas treatment systems, mainly biofilters have been used to control emissions containing ammonia. The main processes taking place during biofiltration of ammonia are presented in Figure 10.

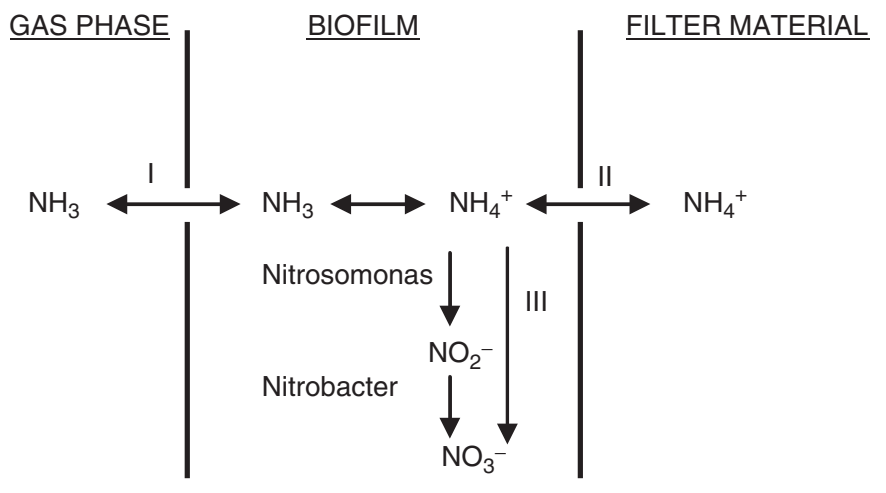

Figure 10. Main processes taking place during ammonia biofiltration (I: absorption; II: adsorption; III: nitrification). 
Since ammonia has a low Henry's law constant $\left(\mathrm{H}_{20}{ }^{\circ} \mathrm{C}=5.6 \times 10^{-4}\right)$ (Perry and Green, 1984) and a protonation constant $\mathrm{pK}_{\mathrm{a}, 20{ }^{\circ} \mathrm{C}}$ of 9.23 (Weast et al., 1984), in biofilters it is partly retained by adsorption onto the carrier material and by absorption into the water fraction of the carrier material. In this context, Shoda (1991) reports a maximum volumetric $\mathrm{NH}_{3}$ elimination capacity of $15 \mathrm{~g}$ $\mathrm{m}^{-3} \mathrm{~d}^{-1}$ in a peat biofilter due to these physical-chemical transfer processes. In a compost biofilter, Smet et al. (2000) obtained an $\mathrm{NH}_{3}$ adsorption and absorption capacity, per volume of compost, of $490 \mathrm{~g} \mathrm{~m}^{-3}$ and $47 \mathrm{~g} \mathrm{~m}^{-3}$, respectively, at an $\mathrm{NH}_{3}$ inlet concentration of $159 \mathrm{ppmv}$ and a compost moisture content of $40 \%$. Next to these physical-chemical processes, nitrification by the autotrophic bacteria Nitrosomonas and Nitrobacter is generally considered as the main microbiological process for the degradation of $\mathrm{NH}_{3}$ (Terasawa et al., 1986; Van Langenhove et al., 1988; Williams, 1995). More recently, the autotrophic genera Nitrosospira and Nitrospira also are reported to be responsible for nitrification (Schramm et al., 2000; Regan et al., 2002).

As a result of these phase transfer and (micro)biological processes, $\mathrm{NH}_{3}$ has been removed efficiently at concentrations up to $50 \mathrm{ppmv}$. Using a wood bark biofilter, Van Langenhove et al. (1988) obtained removal efficiencies of at least $90 \%$ at concentrations between 6 ppmv and 17 ppmv and at $\mathrm{NH}_{3}$ mass loading rates $\left(\mathrm{B}_{\mathrm{v}}\right)$ up to $58 \mathrm{~g} \mathrm{~m}^{-3} \mathrm{~d}^{-1}$. At similar concentrations (4 ppmv to $16 \mathrm{ppmv}$ ), Weckhuysen et al. (1994) observed elimination efficiencies of $83 \%$ or higher at $\mathrm{NH}_{3}$ mass loading rates between $6.8 \mathrm{~g} \mathrm{~m}^{-3} \mathrm{~d}^{-1}$ and $27.2 \mathrm{~g} \mathrm{~m}^{-3} \mathrm{~d}^{-1}$. In an inoculated peat biofilter, $\mathrm{NH}_{3}$ elimination capacities (EC) up to $41 \mathrm{~g} \mathrm{~m}^{-3} \mathrm{~d}^{-1}$ are reported at an inlet concentration of $20 \mathrm{ppmv}$ (Hartikainen et al., 1996). More recently, removal efficiencies as high as $99.5 \%$ were obtained for 100 days in an inoculated perlite biofilter, at concentrations of $50 \mathrm{ppmv}$ and $\mathrm{NH}_{3}$ loading rates between $8.6 \mathrm{~g} \mathrm{~m}^{-3} \mathrm{~d}^{-1}$ and $21.5 \mathrm{~g} \mathrm{~m}^{-3} \mathrm{~d}^{-1}$ (Joshi et al., 2000).

Due to the sensitivity of nitrifying microorganisms, however, biofiltration of waste gases containing high ammonia concentrations (above $50 \mathrm{ppmv}$ ) has been reported to be questionable. Don (1985) and Hartikainen et al. (1996) reported the biofilter removal efficiency for $\mathrm{NH}_{3}$ dropped drastically at waste gas concentrations exceeding $35 \mathrm{ppmv}$ to $60 \mathrm{ppmv}$. However, more recently, Liang et al. (2000) could obtain $\mathrm{NH}_{3}$ removal efficiencies of at least $95 \%$ at inlet concentrations between 20 ppmv and 500 ppmv in compost biofilter in which active carbon was added to reduce compaction and channeling, as well as to increase the reactive surface and durability of the biofilter. Similarly, removal efficiencies over $90 \%$ were achieved by Kim et al. (2002) at inlet concentrations up to $150 \mathrm{ppmv}$ in a biofilter system packed with small cubes of polyurethane sponge coated with a powder mixture of activated carbon and natural zeolite. Kalingan et al. (2004) obtained complete $\mathrm{NH}_{3}$ removal in a peat biofilter containing inorganic supporting material at a $\mathrm{NH}_{3}$ concentration of 200 ppmv, while Smet et al. (2000) observed no $\mathrm{NH}_{3}$-toxicity in a compost biofilter at concentrations up to $775 \mathrm{ppmv}$.

Besides the ammonia input concentration, the mass loading rate of a biofilter seems to be critical for an efficient performance. In an inoculated activated 
carbon biofilter, Yani et al. (1998) found a complete $\mathrm{NH}_{3}$ removal up to $\mathrm{B}_{\mathrm{v}}=95 \mathrm{~g}$ $\mathrm{m}^{-3} \mathrm{~d}^{-1}$, whereas the elimination efficiency decreased at higher loading rates. The highest EC observed by these authors was $220 \mathrm{~g} \mathrm{~m}^{-3} \mathrm{~d}^{-1}$ at $\mathrm{B}_{\mathrm{v}}=250 \mathrm{~g} \mathrm{~m}^{-3} \mathrm{~d}^{-1}$ and at an EBRT of $52 \mathrm{~s}$. Smet et al. (2000) and Demeestere et al. (2002) obtained elimination capacities up to $350 \mathrm{~g} \mathrm{~m}^{-3} \mathrm{~d}^{-1}$ in a compost biofilter at EBRT $=131 \mathrm{~s}$ and $21 \mathrm{~s}$, respectively. EC peak values of $530 \mathrm{~g} \mathrm{~m}^{-3} \mathrm{~d}^{-1}$ and $1285 \mathrm{~g} \mathrm{~m}^{-3} \mathrm{~d}^{-1}$ were reported at inlet concentrations of $250 \mathrm{ppmv}\left(\mathrm{B}_{\mathrm{v}}=600 \mathrm{~g} \mathrm{~m}^{-3} \mathrm{~d}^{-1}\right)$ and $450 \mathrm{ppmv}$ $\left(\mathrm{B}_{\mathrm{v}}=1329 \mathrm{~g} \mathrm{~m}^{-3} \mathrm{~d}^{-1}\right)$, respectively (Demeestere et al., 2002). According to these authors, the cumulative loading (mass of $\mathrm{NH}_{3}$ per filter material volume, $\mathrm{g} \mathrm{m}^{-3}$ ) is the limiting factor for a $\mathrm{NH}_{3}$ degrading biofilter. Smet et al. (2000) observed a sharp reduction in elimination after a cumulative $\mathrm{NH}_{3}$ removal of $6000 \mathrm{~g} \mathrm{~m}^{-3}$. Osmotic effects, due to the accumulation of $\mathrm{NH}_{4} \mathrm{NO}_{\mathrm{x}}$ at concentrations (mass of $\mathrm{NH}_{4} \mathrm{NO}_{\mathrm{x}}-\mathrm{N}$ per mass of compost) higher than $4 \mathrm{~g} \mathrm{~kg}^{-1}$, were found to be the reason for the inhibition of $\mathrm{NH}_{3}$ removal (Smet et al., 2000; Demeestere et al., 2002). However, a subsequent loading of the biofilter with a carbon source like methanol could regenerate the biofilter material, due to methylotrophic conversion of $\mathrm{NH}_{4}^{+}$and $\mathrm{NO}_{\mathrm{x}}{ }^{-}$into biomass (Demeestere et al., 2002).

In order to achieve optimum $\mathrm{NH}_{3}$ removal in biofilters, the moisture content of the filter material should be between $40 \%$ and $60 \%$, the temperature between $30^{\circ} \mathrm{C}$ and $35^{\circ} \mathrm{C}$ and the $\mathrm{pH}$ between 7 and 8 (Van Lith et al., 1997; Warren et al., 1997). With respect to the latter parameter, acidification of the filter material due to the accumulation of nitrite and/or nitrate can inhibit the long-term stability of a $\mathrm{NH}_{3}$ degrading biofilter, as reported by Heller and Schwager (1996). On the other hand, no acidification was observed by Don (1985) and Smet et al. (2000), who attributed that effect to the establishment of an equilibrium between $\mathrm{NH}_{3}$ absorption increasing the $\mathrm{pH}$ and nitrification decreasing the $\mathrm{pH}$.

Next to the removal of $\mathrm{NH}_{3}$ in waste gases by biofiltration, bioscrubbers and biotrickling filters also have been used for $\mathrm{NH}_{3}$ degradation. Due to the presence of a recirculating water phase, both these techniques allow to drain off accumulating toxic compounds, to control the $\mathrm{pH}$, and to add nutrients. As an example, Smits et al. (1995) obtained a biological elimination capacity of $96 \mathrm{~g} \mathrm{~m}^{-3} \mathrm{~d}^{-1}$ in a pilot-scale biotrickling filter at superficial gas and liquid velocities of $1300 \mathrm{~m}$ $\mathrm{h}^{-1}$ and $2.5 \mathrm{~m} \mathrm{~h}^{-1}$, respectively. No gas-to-liquid mass transfer limitation was observed under these conditions. Due to its low Henry's law coefficient, efficient $\mathrm{NH}_{3}$ scrubbing from the gas phase can be obtained. However, it was observed by the authors that up to $70 \%$ of the ammonia removed from the waste gas was not nitrified but removed with the drain water. Consequently, although the use of both biotrickling filters and bioscrubbers can be very efficient to remove $\mathrm{NH}_{3}$ from the waste gas, it implicates the subsequent treatment of the $\mathrm{NH}_{4}^{+}$-loaded drain water in a wastewater treatment plant. Another drawback of these technologies is the relative low removal of less water-soluble odorous compounds in bad-smelling waste gases.

Although it is shown by some authors (Tang et al., 1996; Chou and Shiu, 1997; Busca and Pistarino, 2003; Chang et al., 2004) that also other odorous 
nitrogen-containing compounds than ammonia can be efficiently removed by biological waste gas treatment technologies, fewer experimental data are published so far in that field. For example, as far as we know, there is no information available about the biotechnological removal of nitrogen compounds like amides, indole, scatole, and pyridine. Nevertheless, some reports deal with the removal of gaseous amines by biofiltration. Amines are bad-smelling compounds that often are present in waste gases arising from fish markets, meat treatment industries, and other food industries (Busca and Pistarino, 2003). According to Chou and Shiu (1997), methylamine (MA) can be successfully removed, i.e., hydrolyzed to ammonia and nitrified to nitrate and/or incorporated into microbial biomass, in peat biofilters at mass loading rates up to $160 \mathrm{~g} \mathrm{~m}^{-3} \mathrm{~d}^{-1}$, at a $\mathrm{pH}$ between 7.5 and 8.5, and at a moisture content between 55\% and 60\%. Tang et al. (1996) investigated the removal of triethylamine (TEA, 78 ppmv to $841 \mathrm{ppmv}$ ) in a biofilter consisting of a mixture of compost and chaff particles and obtained the highest TEA elimination capacity of $3360 \mathrm{~g} \mathrm{~m}^{-3} \mathrm{~d}^{-1}$ at an inlet concentration of 550 ppmv, above which substrate inhibition occurred. However, a comprehensive picture cannot be drawn for these compounds due to scarceness of the literature available (Busca and Pistarino, 2003).

\subsection{Removal of Hydrogen Sulfide}

Next to ammonia, $\mathrm{H}_{2} \mathrm{~S}$ biofiltration has been studied extensively, because it is one of the most frequently produced odorous compounds in industrial processes like petroleum refining, rendering, wastewater treatment, food processing, and paper and pulp manufacturing (Yang and Allen, 1994a). The bacteria responsible for $\mathrm{H}_{2} \mathrm{~S}$ degradation in biofilters mostly belong to the genera Thiobacillus (e.g., T. thioparus) and Acidithiobacillus (e.g., A. thiooxidans) and can be either neutrophilic or acidophilic. Under optimal conditions, $\mathrm{H}_{2} \mathrm{~S}$ is oxidized to sulfuric acid, but during stress conditions (high loads, oxygen limitation) accumulation of elemental sulfur has been observed.

Because $\mathrm{H}_{2} \mathrm{~S}$ is very biodegradable, most investigations report very efficient $\mathrm{H}_{2} \mathrm{~S}$ removal in a wide concentration range. Yang and Allen (1994a), for instance, observed higher than $99.9 \%$ removal efficiencies for $\mathrm{H}_{2} \mathrm{~S}$ inlet concentrations ranging from 5 ppmv to $2650 \mathrm{ppmv}$. However, because sulfuric acid is produced, acidification of the filter material will inevitably occur during the biofiltration process, its rate depending on the buffer capacity of the filter bed and the amount of $\mathrm{H}_{2} \mathrm{~S}$ removed. Degorce-Dumas et al. (1997) found that buffering the packing to a near neutral $\mathrm{pH}$ doubled the length of the period during which $>95 \% \mathrm{H}_{2} \mathrm{~S}$ removal efficiency was obtained. When the $\mathrm{pH}$ decreased below 6.6, the $\mathrm{H}_{2} \mathrm{~S}$ removal efficiency started to decrease, together with the number of nonacidifying thiobacilli. Instead, acidifying thiobacilli became dominant. Therefore, a correlation between the number of nonacidifying thiobacilli and the $\mathrm{H}_{2} \mathrm{~S}$ removal efficiency was suggested. Other authors, however, observed a smaller effect of acidic $\mathrm{pH}$ values on the $\mathrm{H}_{2} \mathrm{~S}$ removal efficiency. Yang and Allen (1994a), 
for instance, found almost equal $\mathrm{H}_{2} \mathrm{~S}$ removal efficiencies at $\mathrm{pH}$ values between 3.2 and 8.8. Only at $\mathrm{pH}=1.6$, the removal efficiency decreased to $15 \%$. The high $\mathrm{H}_{2} \mathrm{~S}$ removal efficiency at $\mathrm{pH}=3.2$ was attributed to the abundance of acidophilic sulfur oxidizing bacteria. Also other studies did not report decreased $\mathrm{H}_{2} \mathrm{~S}$ removal efficiencies at $\mathrm{pH}$ values as low as 3 (Wada et al., 1986; Cook et al., 1999) or even 1.2 (Yang et al., 1994). During biofiltration, the $\mathrm{pH}$ will first decrease at the inlet side of the biofilter, where most of the $\mathrm{H}_{2} \mathrm{~S}$ is oxidized and the low $\mathrm{pH}$ front will consequently move to the deeper parts of the biofilter (Cook et al., 1999). In general, it should be sufficient to maintain a $\mathrm{pH}$ value higher than 3 for efficient $\mathrm{H}_{2} \mathrm{~S}$ removal. However, it could be useful to maintain neutral $\mathrm{pH}$ values to prevent inhibition of the removal of other compounds present in the waste gas, corrosion, and increased filter medium degradation. To increase the $\mathrm{pH}$ of the biofilter material, washing can be applied (Yang and Allen, 1994b), although only small pH increases are usually obtained. Smet et al. (1996b) observed that regeneration of an acidified biofilter $(\mathrm{pH}=4.7)$ was not possible by trickling tap water or buffer solution over the bioreactor, because most of the sulfate was leached as the corresponding sulfate salts and not as sulfuric acid. In addition, leaching caused washout of essential microbial elements. Alternatively, the use of more concentrated buffer solutions in combination with a complete mineral medium or mixing with limestone powder was recommended.

Next to acidification, the accumulation of elemental sulfur and sulfate in the filter material can potentially inhibit microbial activity. Yang and Allen (1994b) found the highest concentrations of both compounds at the inlet side of the biofilter. Elemental sulfur was present because it was formed as an intermediate during incomplete $\mathrm{H}_{2} \mathrm{~S}$ oxidation after exposure to high $\mathrm{H}_{2} \mathrm{~S}$ concentrations. By adding increasing amounts of sulfate to different biofilters, Yang and Allen (1994a) observed that concentrations (mass of S per mass of compost) exceeding $25 \mathrm{mg} \mathrm{g}^{-1}$ were inhibitory for $\mathrm{H}_{2} \mathrm{~S}$ removal, probably due to toxic effects. This inhibition effect, however, was not confirmed by Jones et al. (2003), for sulfate concentrations up to $100 \mathrm{mg} \mathrm{g}^{-1}$. In general, it is recommended to evaluate the expected $\mathrm{H}_{2} \mathrm{~S}$ loading rate before designing a biofilter. If it is assumed that all sulfur entering a biofilter will ultimately accumulate as sulfate, its cumulative concentration can be calculated to assess the long-term deactivation of a biofilter, e.g., with a threshold of $25 \mathrm{mg} \mathrm{g}^{-1}$.

Because $\mathrm{H}_{2} \mathrm{~S}$ is very biodegradable, EBRTs can be rather low, e.g., $15 \mathrm{~s}$ (Yang and Allen, 1994a) without affecting the $\mathrm{H}_{2} \mathrm{~S}$ removal efficiency. Possibly other, less biodegradable or water-soluble compounds present in the waste gas will determine the lower limit of the EBRT. Next to organic materials like compost, peat, or wood bark, different alternative carrier materials were described for $\mathrm{H}_{2} \mathrm{~S}$ biofiltration, being rockwool, fuyolite, and ceramics (Kim et al., 1998), a pelletized mixture of pig manure and sawdust (Elías et al., 2000), pellets of agricultural residues (Elías et al., 2000), porous lava inoculated with Thiobacillus thiooxidans (Cho et al., 2000), and microorganisms immobilized in Ca-alginate (Chung et al., 1996a,b, 1997, 1998; Huang et al., 1996; Park et al., 2002). 
Next to biofilter applications, more recent articles describe $\mathrm{H}_{2} \mathrm{~S}$ removal with biotrickling filters. Their main advantage is optimal control of $\mathrm{pH}$, nutrients, and accumulation products, although of course treatment costs are higher. At an EBRT between $30 \mathrm{~s}$ and $120 \mathrm{~s}$, high $\mathrm{H}_{2} \mathrm{~S}$ removal efficiencies (>95\%) easily can be obtained for $\mathrm{H}_{2} \mathrm{~S}$ concentrations between $200 \mathrm{ppmv}$ and $2000 \mathrm{ppmv}$ (Ruokojärvi et al., 2001; Sercu et al., 2005b). At lower influent concentrations, lower EBRTs can be used at high removal efficiencies. Gabriel and Deshusses (2003) described the retrofitting of existing chemical scrubbers for $\mathrm{H}_{2} \mathrm{~S}$ removal to biotrickling filters, maintaining an EBRT between $1.6 \mathrm{~s}$ and $2.2 \mathrm{~s}$. Removal efficiencies $>98 \%$ were commonly reached for $30 \mathrm{ppmv}$ inlet concentrations, with decreases to $90 \%$ at 60 ppmv peak concentrations. The removal of volatile organic sulfur compounds in the same reactor was lower, however, e.g., $35 \%$ $\pm 5 \%$ for carbon disulfide. The authors attributed the residual odor after the biotrickling filter mainly to the persistence of these compounds. Also Wu et al. (2001) obtained $>95 \% \mathrm{H}_{2} \mathrm{~S}$ removal efficiency at EBRT $=5 \mathrm{~s}$, at $<6$ ppmv influent concentrations in a pilot-scale biotrickling filter. At $20 \mathrm{ppmv}$ influent concentration the removal efficiency decreased to about $89 \%$.

\subsection{Removal of Ammonia and Hydrogen Sulfide}

A number of studies have been performed regarding the simultaneous removal of $\mathrm{H}_{2} \mathrm{~S}$ and $\mathrm{NH}_{3}$, because both can constitute an important part of odorous gas mixtures. Similarly as with the removal of the separate compounds, high removal efficiencies can be obtained during simultaneous dosing of both compounds, at concentration levels usually occurring in odorous mixtures ( $<50 \mathrm{ppmv})$. At higher $\mathrm{H}_{2} \mathrm{~S}$ and $\mathrm{NH}_{3}$ concentrations, inhibition of the $\mathrm{NH}_{3}$ removal can occur. Kim et al. (2002), for instance, obtained higher than $99 \%$ and $92 \%$ removal efficiencies for $\mathrm{H}_{2} \mathrm{~S}$ and $\mathrm{NH}_{3}$, respectively, in a wood chips biofilter, at influent concentrations of about $50 \mathrm{ppmv}(\mathrm{EBRT}=1 \mathrm{~min})$. At concentrations exceeding $200 \mathrm{ppmv}$, however, $\mathrm{H}_{2} \mathrm{~S}$ inhibited the $\mathrm{NH}_{3}$ removal, which decreased to $30 \%$, but this effect was reversible when the $\mathrm{H}_{2} \mathrm{~S}$ concentration decreased again. By using a granulated activated carbon biofilter, the inhibition during $\mathrm{H}_{2} \mathrm{~S}$ peak loadings decreased due to buffering effects. An important aspect of simultaneous $\mathrm{H}_{2} \mathrm{~S}$ and $\mathrm{NH}_{3}$ biofiltration is that the extent of the $\mathrm{pH}$ decrease, caused by production of sulfuric and nitric acids, can decrease, because the accumulation of acidic products can be small due to $\left(\mathrm{NH}_{4}\right)_{2} \mathrm{SO}_{4}$ formation. At $\mathrm{NH}_{3}$ concentrations equal or higher than $\mathrm{H}_{2} \mathrm{~S}$ (on volumetric basis), Chung et al. (2000), for instance, observed no acidification. Recently, Chung et al. (2004) showed that acidification during $\mathrm{H}_{2} \mathrm{~S}$ and $\mathrm{NH}_{3}$ removal could further be decreased considerably by selection of heterotrophic bacteria (Pseudomonas putida $\mathrm{CH} 11$ for $\mathrm{H}_{2} \mathrm{~S}$ and Arthrobacter oxydans $\mathrm{CH} 8$ for $\mathrm{NH}_{3}$ ). Heterotrophs oxidize $\mathrm{H}_{2} \mathrm{~S}$ and $\mathrm{NH}_{3}$ mainly to elemental sulfur and organic nitrogen, causing only very small production of acidic end-products. In the activated carbon biofilter, $\mathrm{H}_{2} \mathrm{~S}$ and $\mathrm{NH}_{3}$ concentrations between 20 ppmv and 120 ppmv could be very efficiently removed during $180 \mathrm{~d}$. A carbon source 
had to be supplied every two weeks to support growth of the heterotrophic organisms. A number of researchers used microorganisms immobilized in Ca-alginate to remove mixtures of $\mathrm{H}_{2} \mathrm{~S}$ and $\mathrm{NH}_{3}$, although the performance of these reactors was somewhat lower than with the more traditional biofilters (Chung et al., 2000, 2001a,b). Possible advantages, however, are increased possibilities for $\mathrm{pH}$ control and removal of metabolic products (elemental sulfur and $\left.\left(\mathrm{NH}_{4}\right)_{2} \mathrm{SO}_{4}\right)$, as is also the case with biotrickling filters.

\subsection{Removal of Volatile Organic Sulfur Compounds}

Volatile organic sulfur compounds (VOSCs) include compounds like dimethyl sulfide (DMS), dimethyl disulfide (DMDS), mercaptans, and carbon disulfide. These compounds have been related to odor complaints in some studies. A direct correlation could even be established between the total odor concentration and the concentration of VOSCs in waste gases of rendering plants (Defoer et al., 2002). Van Langenhove et al. (1992) compared a full-scale biotrickling filter and a biofilter for treating rendering emissions. Both techniques removed alkanals very efficiently, but organic sulfur compounds were much less efficiently removed. This was attributed to an insufficient development of microorganisms capable of degrading these compounds. Goodwin et al. (2000) also observed problems removing reduced sulfur compounds with a biofilter at a biosolids composting facility. Increasing the EBRT from $20 \mathrm{~s}$ to $32 \mathrm{~s}$ improved the removal efficiency somewhat. In contrast, VOCs like methane, formaldehyde, isopentanal, N,Ndimethyl methenamine, and dimethylamine were removed for more than $95 \%$ in all cases at average inlet concentrations of $15 \mathrm{ppmv}$.

Different reasons can explain the relation of VOSCs and odor nuisance. First of all, VOSCs combine a very bad smell with very low odor threshold values, for instance $0.1 \mathrm{ppbv}$ to $3.6 \mathrm{ppbv}$ for DMDS and $0.9 \mathrm{ppbv}$ to $8.5 \mathrm{ppbv}$ for methyl mercaptan (Smet et al., 1998). This means that to prevent odor nuisance only very low concentrations can persist in the treated gas stream. Second, compared with $\mathrm{H}_{2} \mathrm{~S}$, VOSCs are less biodegradable. Degradation rates decrease in the order $\mathrm{H}_{2} \mathrm{~S}>\mathrm{MM}>\mathrm{DMDS}>\mathrm{DMS}$ (Cho et al., 1991; Smet et al., 1998). Therefore, it is recommended to inoculate biofilters to shorten the start-up period and to remove high concentrations of these compounds. Smet et al. (1996a), for instance, increased the maximal DMS elimination capacity from $10 \mathrm{~g} \mathrm{~m}^{-3} \mathrm{~d}^{-1}$ to $680 \mathrm{~g} \mathrm{~m}^{-3} \mathrm{~d}^{-1}$ after inoculation of a compost biofilter with Hyphomicrobium MS3. Also other authors used inocula (e.g., Hyphomicrobium spp., Thiobacillus spp.) to remove VOSCs in biofilters (Cho et al., 1991, 1992; Zhang et al., 1991; Park et al., 1993). However, in full-scale applications, the use of inoculation is not well documented. Smet (1995) reported successful removal of organic sulfur compounds in a full-scale biofilter treating emissions from mushroom composting, after inoculation with a specialized strain. Fifty days after inoculation, the total sulfur removal efficiency (excluding $\mathrm{H}_{2} \mathrm{~S}-\mathrm{S}$ ) in the inoculated biofilter section had increased to $99 \%$ compared with $68 \%$ in the noninoculated section. But 
even when inoculation is used, in a mixture of reduced sulfur compounds, $\mathrm{H}_{2} \mathrm{~S}$ is preferentially degraded over dimethyl sulfide or other organic sulfur compounds (Cho et al., 1992; Wani et al., 1999; Zhang et al., 1991). This occurs because $\mathrm{H}_{2} \mathrm{~S}$ oxidation yields most energy for the microorganisms (Smet et al., 1998). Therefore, the bioreactor has to be designed large enough to allow $\mathrm{H}_{2} \mathrm{~S}$ degradation at the inlet side of the biofilter and degradation of the remaining VOSCs deeper in the biofilter bed. Finally, when a biofilter is designed properly to remove VOSCs, there is still a change of long-term decrease in removal efficiency because of acidification. Similarly as for $\mathrm{H}_{2} \mathrm{~S}$, sulfuric acid is formed after complete oxidation of VOSCs. Microorganisms degrading the VOSCs, however, are much more sensitive to low $\mathrm{pH}$ values than $\mathrm{H}_{2} \mathrm{~S}$ oxidizing bacteria. Smet et al. (1996b), for instance, observed a decreased DMS elimination capacity when the compost $\mathrm{pH}$ decreased below 5. To prevent problems due to acidification, the bioreactor has to be designed large enough, and for high influents loadings $\mathrm{pH}$ control should be included. Alternatively, two-stage systems have been proposed, first removing $\mathrm{H}_{2} \mathrm{~S}$ and subsequently VOSCs (Kasakura and Tatsukawa, 1995; Park et al., 1993; Ruokojarvi et al., 2001; Sercu et al., 2005b). Ruokojarvi et al. (2001), for instance, developed a two-stage biotrickling filter for sequential removal of $\mathrm{H}_{2} \mathrm{~S}$, methyl mercaptan (MM) and DMS. Two bioreactors connected in series were inoculated with enriched activated sludge, the first operating at low $\mathrm{pH}$ for $\mathrm{H}_{2} \mathrm{~S}$ removal and the second at neutral $\mathrm{pH}$ for DMS removal. MM was removed in both reactors. $\mathrm{H}_{2} \mathrm{~S}$, DMS and MM elimination capacities (as $\mathrm{S}$ ) as high as $47.9 \mathrm{~g}$ $\mathrm{m}^{-3} \mathrm{~h}^{-1}, 36.6 \mathrm{~g} \mathrm{~m}^{-3} \mathrm{~h}^{-1}$ and $2.8 \mathrm{~g} \mathrm{~m}^{-3} \mathrm{~h}^{-1}$, respectively, were obtained for the entire two-stage biotrickling filter at $>99 \%$ removal efficiencies and the reactor showed a good long-term stability.

\subsection{Removal of Odorous VOCs}

Generally, odorous VOCs are biodegradable in biofilters (Van Langenhove et al., 1989b, 1992; Goodwin et al., 2000). In most cases these compounds are not the cause of odor problems when biofilter malfunctioning occurs, and therefore literature data about the removal of low concentrations of these compounds are less available than, for example, ammonia and hydrogen sulfide.

The removal of aldehydes, alcohols, and fatty acids is generally very good in biofilters (Kiared et al., 1997; Mohseni and Allen, 2000; Otten et al., 2004; Sheridan et al., 2003; Weckhuysen et al., 1993). For methanol, for instance, it was, found that concentration step changes and periods without methanol loading did not affect its removal efficiency in biofilters (Mohseni and Allen, 1999), which was attributed to the good biodegradability and high water solubility of methanol. In some studies it was shown that nutrient addition could enhance VOC elimination capacities during longer periods, e.g., in the case of butanal (Weckhuysen et al., 1993) or butyric acid (Sheridan et al., 2003). It has been observed that in the case of aldehydes, the corresponding organic acids can accumulate during biofiltration, especially at higher influent concentrations 
(Weckhuysen et al., 1993; Sercu et al., 2005a). This can lead to a $\mathrm{pH}$ decrease, potentially limiting the removal efficiencies of other compounds in the waste gas. Next to biofilters, biotrickling filters have been used to remove odorous VOCs. Again, high removal efficiencies have been obtained for aldehydes, alcohols, and volatile fatty acids (Chang and Lu, 2003; Chua et al., 2000; Ibrahim et al., 2001; Kirchner et al., 1991), even at low EBRT. Kirchner et al (1987), for instance, showed $>90 \%$ removal efficiencies for compounds like aldehydes and alcohols at 5 ppmv to 40 ppmv influent concentrations and 2.4 s EBRT. Ibrahim et al. (2001) found $92 \%$ and $95 \%$ removal efficiencies for $10 \mathrm{ppmv}$ acetaldehyde and propionaldehyde inlet concentrations, respectively, in a column packed with immobilized activated sludge beads at EBRT $=12.4 \mathrm{~s}$. At higher influent concentrations, the removal of both compounds decreased, however, due to inhibitory effects. For higher influent concentrations, higher EBRT values are needed, as shown by Chang and $\mathrm{Lu}$ (2003). They found nearly complete isopropanol removal efficiencies in a biotrickling filter, operated between $20 \mathrm{~s}$ and $90 \mathrm{~s}$ EBRT time at influent concentrations between $100 \mathrm{ppmv}$ and $500 \mathrm{ppmv}$. When too high influent loadings are applied, accumulation of compounds or intermediates can occur. Chua et al. (2000) found $>99 \%$ removal efficiencies for butyric and valeric acid in a biotrickling filter, at mass loadings between $4.8 \mathrm{~g} \mathrm{~m}^{-3} \mathrm{~h}^{-1}$ and $37.8 \mathrm{~g} \mathrm{~m}^{-3}$ $\mathrm{h}^{-1}\left(0.05 \mathrm{~g} \mathrm{~m}^{-3}\right.$ to $\left.0.86 \mathrm{~g} \mathrm{~m}^{-3}\right)$. However, at loading rates exceeding $32 \mathrm{~g} \mathrm{~m}^{-3} \mathrm{~h}^{-1}$, the maximal biodegradation capacity was reached and accumulation of volatile fatty acids in the liquid phase was observed.

\subsection{Removal of Odor Mixtures}

From the previous sections, it is clear that most of the components present in odorous mixtures can be removed efficiently with biological waste gas cleaning techniques, when properly operated, even at relatively high influent concentrations. Also, in industrial applications treating mixtures of compounds, often high (odor) removal efficiencies can be obtained. Park et al. (2001), for instance, used a biotrickling filter packed with ceramics and inoculated with activated sludge to remove odors at a composting facility. After a $30 \mathrm{~d}$ acclimation period, $>95 \%$ removal efficiencies were obtained for $\mathrm{NH}_{3}$ and $\mathrm{H}_{2} \mathrm{~S}$ during about $60 \mathrm{~d}$ of operation. Also, at a biosolids composting facility, Goodwin et al. (2000) found efficient odor removal with a biofilter $(>95 \%)$ after about 3 months of operation at EBRT $=20 \mathrm{~s}$, as determined with olfactometric analyses. Luo (2001) observed > $98 \%$ odor reduction with wood bark biofilters treating rendering emissions during a period of 3 years, at EBRT $=6.8 \mathrm{~min}$. Reducing the EBRT to $1.7 \mathrm{~min} \mathrm{did}$ not affect the odor removal efficiencies during the first 3 months of operation. After 22 months, however, the odor removal efficiency was $99.1 \%$ at EBRT $=6.8 \mathrm{~min}$ and only $29.7 \%$ at EBRT $=1.7 \mathrm{~min}$. This clearly shows that regular filter medium replacement is necessary, especially when lower EBRT values are used.

When a complex mixture of odorous compounds has to be treated, removal efficiencies of the single compounds can be smaller than expected. This can be 
caused by, e.g., toxic effects of substrates or metabolites. Van Langenhove et al. (1989a) compared the applicability of a tree bark biofilter for removing odors from a vegetable processing industry, mainly emitted during the blanching process. The main odorous compounds identified were sulfides, isothiocyanates, nitriles, and aldehydes. In pilot-scale experiments all compounds were removed with $>95 \%$ removal efficiencies at a volumetric loading rate of $200 \mathrm{~m}^{3} \mathrm{~m}^{-2} \mathrm{~h}^{-1}$. However, a full-scale biofilter, designed according to the results obtained from the pilot-scale studies, had lower removal efficiencies after 6 months of operation ( $45 \%$ to $65 \%$ for sulfides). This was found to be caused by the accumulation of isothiocyanates, which was not observed during the short-term pilot-scale experiments. For hexanal, Van Langenhove et al. (1989b) observed 85\% removal efficiency in a wood bark biofilter, at 10 ppmv inlet concentration and EBRT = $0.33 \mathrm{~min}$. To simulate emissions from a food processing plant, $40 \mathrm{ppmv} \mathrm{SO}_{2}$ was added to the waste stream, leading to a drastic decrease of the hexanal removal efficiency to $40 \%$. Next to toxic effects, preferential degradation of easily biodegradable compounds can inhibit the removal of other compounds. Smet et al. (1997), for instance, found that isobutanal was preferentially degraded before DMS, in a biofilter inoculated with Hyphomicrobium MS3, when both compounds were simultaneously dosed. This could cause low removal of DMS when a biofilter is designed too small.

\section{CASE STUDIES}

\subsection{Methodology}

In all case studies mentioned in this paragraph, samples have been taken of the untreated and the treated airflows, in order to determine important parameters. First, the chemical composition of the airflow was revealed using GC-MS analysis. These data are very useful for the determination of the total chemical load going to the bioreactor, as well as for improving the working efficiency of it, being able to indicate the compounds or groups of compounds that are degraded insufficiently. The second type of analyses used is the determination of the total odor concentration, using dynamic olfactometry. These data are used to determine the total odor removal efficiency of the bioreactor, which is the final wanted effect of the use of a bioreactor in case of odor problems.

\subsubsection{GC-MS Analysis}

4.1.1a. Sampling procedure. The gases were sampled using a method that involved preconcentration on an adsorbent. This preconcentration step was carried out at the sampling location. Tenax TA was used as adsorbent. Tenax TA is a porous polymer based on 2,6-diphenylene oxide. It has been specifically designed for the trapping of volatiles and semivolatiles (SIS, 2000). The collected 
waste gases were cooled at about $4{ }^{\circ} \mathrm{C}$ before adsorption. This cooling stage was used in order to increase the breakthrough volume and in order to separate excess water vapor. The sampled adsorption tubes were filled with approximately $750 \mathrm{mg}$ Tenax. Sampling rate was $200 \mathrm{ml} \mathrm{min}^{-1}$ and sampled volume varied between $50 \mathrm{ml}$ and $10 \mathrm{~L}$.

4.1.1b. Analysis. The analysis of the VOCs present in the sample was done in different steps, including desorption from the adsorbent, separation by gas chromatographic techniques, quantification by flame ionization detection, and subsequent identification through mass spectrometry. The desorption step consisted of a thermal desorption. A second preconcentration (cryogenic trapping of the VOCs) was necessary in order to achieve good chromatographic separation. The cryogenically concentrated samples were introduced immediately into the GC by rapid heating of the trap. The different compounds were separated in a gas chromatograph (Varian 2700) with a $100 \%$ polydimethylsiloxane apolar column (type DB-1, $30 \mathrm{~m} \times 0.53 \mathrm{~mm}$, film thickness $5 \mu \mathrm{m}, \mathrm{J} \& \mathrm{~W}$ Scientific). The mass spectrometer used was a Finnigan MAT $112 \mathrm{~S}$ with an electron impact ion source and a magnetic sector analyser.

\subsubsection{Olfactometry}

4.1.2a. Sampling procedure. The gases were sampled using the static sampling method. In this method, a sample is collected and transferred into a sampling container (bag). Collecting the sample was done with the "lung principle," where the sample bag is placed in a rigid container and the air is removed from the container using a vacuum pump. The partial vacuum created in the container causes the bag to fill with a volume of sample equal to the volume that was removed from the space around the bag in the rigid container. In some sampling points, where a risk of condensation in the sampling bag existed due to high humidity and high temperatures, a predilution was applied using dry odor-free nitrogen. Sampling materials used were Teflon ${ }^{\mathrm{TM}}$ for tubing and disposable sampling bags made of Nalophan ${ }^{\mathrm{TM}}$ film. All samples were analyzed by the accredited odor laboratory of PRA OdourNet bv (The Netherlands) within 30 hours after sampling. During transportation, samples were not exposed to direct sunlight. All measurements of the odor concentrations were executed by dynamic olfactometry according to the EN13725 (CEN, 2003).

4.1.2b. Principle of dynamic olfactometry. The odor concentration of a gaseous sample of odorants is determined by presenting a panel of selected and screened human subjects with that sample, varying the concentration by diluting with neutral gas, in order to determine the dilution factor at the $50 \%$ detection threshold. At that dilution factor, the odor concentration is $1 \mathrm{ou}_{\mathrm{E}} \mathrm{m}^{-3}$ by definition. The odor concentration of the examined sample is then expressed 
as a multiple of one European odor unit per cubic meter $\left(\mathrm{ou}_{\mathrm{E}} \mathrm{m}^{-3}\right)$ at standard conditions for olfactometry.

\subsection{Odor Removal at a Vegetable Oil Extraction Plant}

\subsubsection{Background (Van Elst and Van Langenhove, 2001)}

Crushing and extraction plants for vegetable oils often cause considerable emissions of odor, which may cause offense in nearby residential areas. The type of oil seed processed partially determines the amount and type of odor released. Only limited information is found in literature on the composition of these waste gases, on source strength classification, and on possible treatment methods. Lacoste et al. (1996) performed a quantitative study of odorous compounds in gas effluents from three rapeseed crushing plants. Olfactometry was used to determine odor concentrations of gaseous effluents. Chemical analyses revealed the presence of nitriles, aldehydes, and sulfur compounds like mercaptans in conditioning and pressing emissions, while hydrogen sulfide and acetaldehyde were the major odorant compounds in the absorption unit effluents.

An oil crushing and extraction plant, situated in an industrial area in the northern part of France, mainly processes soybean, sunflower, and rapeseed to produce vegetable oils. Significantly higher odor emissions occurred when processing rapeseed (colza) compared to those associated with other types of oil seed. Because of the growing number of complaints arising from the surrounding residential area at distances of more than one kilometre, the plant management decided to tackle the odor problem. The process of improving the odor situation in the vicinity of this plant was a process that took several years and included various types of measurements and interim evaluations. The measurements were a combination of chemical analyses, olfactometry, and field panels. Chemical measurements (gas chromatography, combined with mass spectrometry) were mainly used to get a better understanding of the composition of the different waste gas streams on the plant. Different gas streams have been sampled to identify and quantify the VOCs present. In the interpretation, special emphasis was put on compounds with a low odor threshold. Olfactometric measurements were used to determine the total amount of odour present in the waste gas stream. These data were very useful to make a classification of the different sources in order to set priorities for abatement but also to calculate the total odor abatement efficiency of treatment systems. Field panel measurements determined the impact of the total odor emission on the vicinity of the plant.

\subsubsection{Identification of the Main Sources}

The first step in the processing of the seeds consists of a number of physical treatments, like cleaning, crushing, heating up to $60^{\circ} \mathrm{C}$, pressing, and cooling. The main odor sources in this treatment are the hot and humid vapors that 
arise at the heating stage and during pressing. Also the cooling of the material before entering the extraction unit, which takes place on the open conveyor belt between the crushing and the extraction unit, can be considered as an important source. The residual oil is then extracted from the flakes with hexane in an extraction unit. Hexane and oil are separated in a distillation unit. The residual fraction of the seed is treated in a desolventizer to remove hexane. Before being vented in the atmosphere, the vapors of the extraction process pass through an absorption system with mineral oil to recapture hexane. The emissions of the absorption contain high concentrations of hydrogen sulfide, and thus represent an important odor source. The extracted residue of the seed is dried and cooled and sold as livestock feed. Large amounts of fresh air are used in this process and are emitted to the atmosphere, loaded with odorous components. Olfactometric emission measurements of a selected number of odor sources resulted in the following emissions (see Table 2).

The vapors of the conditioners were already incinerated in both steam boilers with an odor removal efficiency higher than $90 \%$. The resulting calculated emissions in European odor units per hour demonstrate the importance of the emission of the absorption unit on one hand (72\%) and of the drying-cooling unit on the other hand (18\%).

Chemical measurements were carried out on the six sampled emission points. Table 3 gives an overview of the compounds per chemical group. The data in Table 3 are the emitted mass flows per hour for five sampling points (conditioners not included). The results of the chemical measurements show an important contribution of mainly organic sulfur compounds and hydrogen sulfide to the total odor concentration, considering their low odor threshold. Though no data were found on the odor threshold of the specific nitriles and 4-isothiocyanato-1-butene, there might be an important influence of these compounds to the global odor concentration. The high hydrocarbon content in absorption, conveyor belt, and drying-cooling are mainly caused by the presence of hexane as extraction solvent (hexane, 2-methylpentane, 3-methylpentane, cyclohexane, methylcyclopentane).

Table 2. Odor Concentrations Measured at Six Points in the Process

\begin{tabular}{lllll}
\hline & $\begin{array}{l}\text { Odor } \\
\text { concentration } \\
\left(\mathrm{ou}_{\mathrm{E}} \mathrm{m}^{-3}\right)\end{array}$ & $\begin{array}{l}\text { Total flow } \\
\text { rate per } \\
\text { source }\left(\mathrm{m}^{3} \mathrm{~h}^{-1}\right)\end{array}$ & $\begin{array}{l}\text { Total odor } \\
\text { emission } \\
\left(\mathrm{ou}_{\mathrm{E}} \mathrm{h}^{-1}\right)\end{array}$ & $\begin{array}{l}\text { Percentage of } \\
\text { measured } \\
\text { emission }(\%)\end{array}$ \\
\hline $\begin{array}{l}\text { Vapors of conditioners } \\
\text { Exhaust steam boiler }\end{array}$ & $\begin{array}{l}46 \times 10^{3} \\
\text { Pression point }\end{array}$ & 10300 & - & - \\
Presses & $425 \times 10^{3}$ & 32200 & $29 \times 10^{6}$ & 0.9 \\
Absorption unit & $5564 \times 10^{3}$ & 195 & $83 \times 10^{6}$ & 2.7 \\
Conveyor belt from & 400 & $2225 \times 10^{6}$ & 72.1 \\
extraction to drying unit & $515 \times 10^{3}$ & 350 & $180.10^{6}$ & 5.8 \\
Drying/cooling unit & $8.8 \times 10^{3}$ & 64700 & $570 \times 10^{6}$ & 18.5 \\
\hline
\end{tabular}


Table 3. Mass Flows in $\mathrm{g} \mathrm{h}^{-1}$ for the Different Emission Points

\begin{tabular}{llllll}
\hline & $\begin{array}{l}\text { Boiler } \\
\text { exhaust }\end{array}$ & Presses & Absorption & Conveyor belt & $\begin{array}{l}\text { Drying- } \\
\text { cooling }\end{array}$ \\
\hline Hydrocarbons & 0.27 & 3.1 & 470 & 395 & 3940 \\
Aldehydes & 1.2 & 12 & 25 & 7.1 & 60 \\
Ketones & 0.35 & 1.5 & 1.2 & 1 & 16 \\
Alcohols & - & 7.7 & - & 0.05 & 3 \\
Nitriles & 0.35 & 17 & - & 151 & 3600 \\
Organic sulfur compounds & - & 6.5 & 35 & 0.4 & 15 \\
4-isothio-cyanato-1-butene & - & 0.7 & - & 0.2 & 7 \\
Hydrogen sulfide & - & 0.89 & 1822 & - & - \\
\hline
\end{tabular}

\subsubsection{Abatement Techniques}

As a first abatement step, some high concentrated streams limited in volumetric flow were chosen to be incinerated in the existing steam boilers (i.e., waste gases coming from the absorption unit and presses). As a second step, a suitable technique was chosen for the flow coming from the drying-cooling unit. This waste gas stream, relatively low in concentration but high in volumetric flow, was decided to be treated in a biofilter system after doing some pilot tests. A biofilter combined with a scrubber, designed for a flow of $100.000 \mathrm{~m}^{3} \mathrm{~h}^{-1}$, was constructed by Monsanto EnviroChem systems and operation started in April 1998.

A collecting chamber was installed to receive all waste gas flows. The purpose of this chamber was to create a velocity drop and separate residual dust. The scrubber had three main purposes: capture of small dust particles, humidification of the airstream up to $100 \%$, and cooling up to $37^{\circ} \mathrm{C}$. The biofilter itself is a closed, top-down model. The biofilter material consists of small polystyrene balls surrounded with compost. Inside of the filter are two stages, each subdivided in different compartments, with load measuring cells. These cells measure the weight of the compartment, and depending on the weight, additional water can be sprinkled if dehydration is stated. Figure 11 shows the scrubber, the front side of the biofilter, and the extraction fan and the silencer, both positioned behind the biofilter.

Triplicate olfactometric control measurements (June and July 1998) of the ingoing and outgoing odor concentrations, as well as the chemical composition of both flows, confirmed the good odor removal efficiency of the complete system, with a low residual odor concentration (see Table 4). The chemical composition of the waste gas at the outlet of the biofilter only revealed hydrocarbons (hexane, etc.) above the detection limit. Afterward (August 1998), some smaller but concentrated waste gas streams were added to the collecting chamber, which resulted in a complete solution of the odor problem after three years of analyses and investments. Table 4 shows that though the inlet concentration increased over the different measurements, the outlet concentrations were relatively constant. 

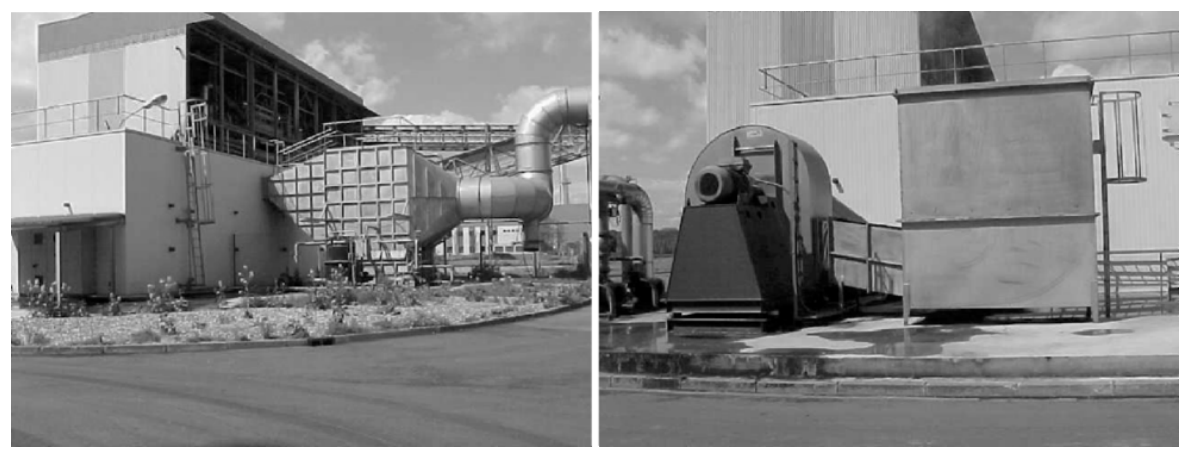

Figure 11. Scrubber and biofilter (left); fan and silencer (right).

Table 4. Average Odor Concentrations Measured at the Biofilter

\begin{tabular}{llll}
\hline Date & $\begin{array}{l}\text { Concentration } \\
\text { at inlet scrubber }\left(\mathrm{ou}_{\mathrm{E}} \mathrm{m}^{-3}\right)\end{array}$ & $\begin{array}{l}\text { Concentration at } \\
\text { outlet biofilter }\left(\mathrm{ou}_{\mathrm{E}} \mathrm{m}^{-3}\right)\end{array}$ & $\begin{array}{l}\text { Removal } \\
\text { efficiency (\%) }\end{array}$ \\
\hline June 1998 & 3935 & 622 & 84.2 \\
July 1998 & 11787 & 1670 & 85.8 \\
July 1998 & 33914 & 1964 & 94.2 \\
Sept 1998 & 165537 & 1277 & 99.2 \\
\hline
\end{tabular}

A value between 1000 and $2000\left(\mathrm{ou}_{\mathrm{E}} \mathrm{m}^{-3}\right)$ can be considered as a normal background value for the typical "own smell" of a good working biofilter. In some cases, still lower values are possible (up to $500 \mathrm{ou}_{\mathrm{E}} \mathrm{m}^{-3}$ ).

\subsection{Odor Removal at an Animal Rendering Plant}

Rendering is the transformation of animal by-products into stable products mainly by evaporation of the water and separation of the fat. Fresh animal by-products start to decompose as soon as the animal has been slaughtered into mainly volatile substances through anaerobic processes often initiated by the bacteria of the stomach and intestinal contents. The volatile substances are set free when the raw material is heated and dried (water evaporation). They are found in the water vapor and part of them are condensed with the water to be treated in wastewater treatment plants, whereas others remain in the gaseous phase (noncondensables) depending on the vapor pressure under the given condensation conditions (Oberthür and Vossen, 2001). The odorous substances from rendering originate mainly from the proteins in the animal byproducts through anaerobic decomposition. The main constituents of rendering odors are hydrogen sulfide, ammonia, organic sulfides, aldehydes, organic acids, and other minor compounds, which due to their low odor threshold, 
however, might contribute in a characteristic way to the rendering odor (VDI, 1996). Due to the nature of the material processed, animal rendering activities thus result in the emission of volatiles and disgusting odors, causing nuisance in the factory's neighborhood (De Roo and Van Langenhove, 2000). Several technologies such as thermal or catalytic combustion, stage scrubbers, and biofilters may be used for the elimination of volatiles from waste gases.

In the investigated rendering plant, the noncondensable gases are incinerated in the steam boilers, resulting in a highly efficient odor removal. The other odorous waste gases are treated in different biofilters, each preceeded with a scrubber using normal water as scrubbing liquid.

The so-called category one material (cadavers, destruction blood, slaughterhouse by-products) is processed in one production line (ca. 300.000 ton year $^{-1}$ ). On this line, two large, conventional biofilter units are in use. Biofilter 1 treats the waste air coming from the "clean zone." General building extraction is used to avoid diffusive emissions, as well as point suction on all process units. Biofilter 1 is divided in two parts (1A and 1B); both airflows could be monitored separately.

Biofilter 2 treats the waste air coming from the "unclean zone" (building extraction and point suction on breakers, pasteurization tanks, buffer tanks, etc.). In a separate production line, animal by-products of poultry are processed for use in petfood (ca. 100.000 tonnes year ${ }^{-1}$ ). Biofilter 3 treats the air coming from this separate poultry line.

In the period between 1998 and 2002 the in- and effluent gas flows have been monitored by olfactometry and GC-MS analyses (unpublished reports Project Research Gent). Table 5 gives an overview of the different chemical compounds found in the waste gas streams.

Defoer et al. (2002) showed that the presence and concentration of the organic sulfur compounds is determining for the total odor concentration of the flow. A direct correlation could be established. For this reason, only the total

Table 5. Overview of Different Chemical Compounds in Rendering Air

\begin{tabular}{ll}
\hline Compound class & Chemicals identified \\
\hline Hydrocarbons & $\begin{array}{l}\text { Pentane, hexane, heptane, octane, nonane, decane, undecane, dodecane, } \\
\text { tridecane, 2-methylpentane, 3-methylpentane, benzene, toluene, ethylben- } \\
\text { zene, o, m, p-xylene, methylethylcyclohexane, methylcyclopentane }\end{array}$ \\
& $\begin{array}{l}\text { Ethanol, 3-methylbutanol } \\
\text { Dimethyl sulfide, dimethyl disulfide, dimethyl trisulfide, carbon disulfide }\end{array}$ \\
Alcohols & $\begin{array}{l}\text { Trifluoromethylbenzene, 1-chlorobutane, tetrachloroethylene, } \\
\text { dichloromethane }\end{array}$ \\
Halogenated VOCs & 2-Methyl-1,3-dioxolane \\
Ethers & Furane, 2-methylfurane \\
Furanes & Acetone, 2-butanone \\
Ketones & 3-Methylbutanal, 2-methylbutanal, n-hexanal, isobutyraldehyde, \\
Aldehydes & benzaldehyde \\
\end{tabular}


Table 6. Overview of the Results

\begin{tabular}{llllrr}
\hline & & $\begin{array}{c}\text { Odour in } \\
\left(10^{3} \mathrm{ou}_{\mathrm{E}} \mathrm{m}^{-3}\right)\end{array}$ & Odour out & VOSCs in & $\begin{array}{c}\text { VOSCs out } \\
\left(\mu \mathrm{g} \mathrm{m}^{-3}\right)\end{array}$ \\
\hline BF 1A & 1998 & 638 & 14 & 1815 & 200 \\
& 2000 & 118 & 1.7 & 322 & 12 \\
$\mathrm{BF} 1 \mathrm{~B}$ & 1998 & 267 & 5 & 130 & 200 \\
& 2000 & 48 & 3.8 & 100 & 10 \\
$\mathrm{BF} 2$ & 2000 & 172 & 48 & 569 & 438 \\
& 2002 & 163 & 4 & 400 & 7 \\
$\mathrm{BF} 3$ & $9 / 1999$ & 1339 & 297 & 4599 & 3277 \\
& $12 / 1999$ & 128 & 3.5 & 193 & 15 \\
& 2000 & 240 & 84 & 931 & 531 \\
& 2002 & 19 & 6 & & Not measured \\
\hline
\end{tabular}

odor concentration (expressed in $\mathrm{ou}_{\mathrm{E}} \mathrm{m}^{-3}$ ) and the concentration of volatile organic sulfur compounds (expressed in $\mathrm{ou}_{\mathrm{E}} \mathrm{m}^{-3}$ ) are shown in Table 6.

This set of data shows that even with high influent odor concentrations, low outlet concentrations can be reached. However, it seems to be difficult to reach a "normal" background value situating between 1000 and $2000 \mathrm{ou}_{\mathrm{E}} \mathrm{m}^{-3}$. This can be caused by two factors:

- the influent concentrations are quite variable due to different processes; peak loads can be negative for the efficiency of the biofilter; and

- the presence of the volatile organic sulfur compounds cause the typical smell of the waste air; as mentioned above VOSCs are less biodegradable, unless the biofilter is inoculated with sulfur-degrading microorganisms.

\section{ACRONYMS AND ABBREVIATIONS}

$\begin{array}{ll}\text { B }_{\mathbf{v}} & \text { Mass loading rate } \\ \text { BPT } & \text { Biological plate tower } \\ \text { DMS } & \text { Dimethyl sulphide } \\ \text { DMDS } & \text { Dimethyl disulphide } \\ \text { EBRT } & \text { Empty bed residence time } \\ \text { EC } & \text { Elimination capacity } \\ \text { MM } & \text { Methyl mercaptan } \\ \text { ppbv } & \text { Parts per billion volume } \\ \text { ppmv } & \text { Parts per million volume } \\ \text { TEA } & \text { Triethyl amine } \\ \text { VOC(s) } & \text { Volatile organic compound(s) } \\ \text { VOSC(s) } & \text { Volatile organic sulphur compounds(s) }\end{array}$




\section{REFERENCES}

Busca, G., Pistarino, C. (2003) "Abatement of ammonia and amines from waste gases: a summary." $16: 157$.

CEN (2003) EN 13725, Air quality - determination of odour concentration by dynamic olfactometry, European Standard, Brussels, Belgium.

Chang, C.-T., Chen, B.-Y., Shiu, I.-S., Jeng, F.-T. (2004) Biofiltration of trimethylamine-containing waste gas by entrapped mixed microbial cells, Chemosphere 55:751.

Chang, K., Lu, C. (2003) Biofiltration of isopropyl alcohol in a trickle-bed air biofilter, Biodegradation 14:9.

Cho, K.-S., Hirai, M., Shoda, M. (1991) Degradation characteristics of hydrogen sulfide, methanethiol, dimethyl sulfide and dimethyl disulfide by Thiobacillus thioparus DW44 isolated from peat biofilter, J. Ferment. Bioeng. 71:384.

Cho, K.-S., Hirai, M., Shoda, M. (1992) Enhanced removability of odorous sulphur-containing gases by mixed cultures of purified bacteria from peat biofilters, J. Ferment. Bioeng. 73:219.

Cho, K.-S., Ryu, H. W., Lee, N. Y. (2000) Biological deodorization of hydrogen sulfide using porous lava as a carrier of Thiobacillus thiooxidans, J. Biosci. Bioeng. 90:25.

Chou, M.-S., Shiu, W.-Z. (1997) Bioconversion of methylamine in biofilters, J. Air Waste Manage. Assoc. 47: 58.

Chua, H., Li, X. Z., Yu, P. F. H., Tam, C. Y., Huang, Y. L., Yang, S. T. (2000) Design and performance of a fibrous bed bioreactor for odor treatment, Appl. Biochem. Biotechnol. 84-86:469.

Chung, Y.-C., Huang, C., Liu, C. H., Bai, H. (2001a), Biotreatment of hydrogen sulfide- and ammoniacontaining waste gases by fluidized bed bioreactor, J. Air Waste Manage. Assoc. 51:163.

Chung, Y.-C., Huang, C., Pan, J. R., Tseng, C.-P. (1998) Comparison or autotrophic and mixotrophic biofilters for $\mathrm{H}_{2} \mathrm{~S}$ removal, J. Environ. Eng. April 1998:362.

Chung, Y.-C., Huang, C. P., Tseng, C.-P. (1996a), Biodegradation of hydrogen sulfide by a laboratoryscale immobilized Pseudomonas putida CH11 biofilter, Biotechnol. Prog. 12:773.

Chung, Y.-C., Huang, C. P., Tseng, C.-P. (1996b), Operation optimization of Thiobacillus thioparus CH11 biofilter for hydrogen sulfide removal, J. Biotechnol. 52:31.

Chung, Y.-C., Huang, C. P., Tseng, C.-P. (1997) Removal of hydrogen sulphide by immobilized Thiobacillus sp. strain CH11 in a biofilter, J. Chem. Technol. Biotechnol. 69:58.

Chung, Y.-C., Huang, C., Tseng, C.-P. (2001b), Biological elimination of $\mathrm{H}_{2} \mathrm{~S}$ and $\mathrm{NH}_{3}$ from waste gases by biofilter packed with immobilized heterotrophic bacteria, Chemosphere 43:1043.

Chung, Y.-C., Huang, C. P., Tseng, C.-P., Pan, J. R. (2000) Biotreatment of $\mathrm{H}_{2} \mathrm{~S}$ - and $\mathrm{NH}_{3}$-containing waste gases by co-immobilized cells biofilter, Chemosphere 41:329.

Chung, Y.-C., Lin, Y.-Y., Tseng, C.-P. (2004) Operational characteristics of effective removal of $\mathrm{H}_{2} \mathrm{~S}$ and $\mathrm{NH}_{3}$ waste gases by activated carbon biofilter, J. Air Waste Manage. Assoc. 54:450.

Cook, L. L., Gostomski, P. A., Apel, W. A. (1999) Biofiltration of asphalt emissions: full-scale operation treating off-gases from polymer-modified asphalt production, Environ. Prog. 18 :178.

De Bo, I. (2002) Membrane biofiltration of single-compound waste gas streams, PhD thesis, Ghent University, Belgium.

De Bo, I., Heyman, J., Vincke, J., Verstraete, W., Van Langenhove, H. (2003) Dimethyl sulfide removal from synthetic waste gas using a flat poly(dimethylsiloxane)-coated composite membrane bioreactor, Environ. Sci. Technol. 37:4228.

De Bo, I., Jacobs, P., Van Langenhove, H. (2002) Removal of toluene and trichloroethylene from waste air in a membrane bioreactor, Environ. Sci. Pollution Res. Special Issue 3:28.

Defoer, N., De Bo, I., Van Langenhove, H., Dewulf, J., Van Elst, T. (2002) Gas chromatographymass spectrometry as a tool for estimating odour concentrations of biofilter effluents at aerobic composting and rendering plants, J. Chromatogr. A 970:259.

Degorce-Dumas, J. R., Kowal, S., Le Cloirec, P. (1997) Microbiological oxidation of hydrogen sulphide in a biofilter, Can. J. Microbiol. 43:264. 
Demeestere, K., Van Langenhove, H., Smet, E. (2002) Regeneration of a compost biofilter degrading high loads of ammonia by addition of gaseous methanol, J. Air Waste Manage. Assoc. 52:796.

De Roo, K., Van Langenhove, H. (2000) Emissions from animal rendering, in: Proceedings of the 7th symposium on analytical and environmental problems, Z. Galbacs, ed., Szeged, Hungary, October 2, 2000, p. 38.

Devinny, J. S., Deshusses, M. A., Webster, T. S. (1999) Biofiltration for Air Pollution Control. CRC Press LLC, Boca Raton.

Devos, M., Patte, F., Rouault, J., Laffort, P., Van Gembert, L. J. (1990) Standardized Human Olfactory Thresholds, Oxford University Press, Oxford, 165 p.

Don, J. A. (1985) The rapid development of biofiltration for the purification of diversified waste gas streams, VDI Berichte 561:63.

Elías, A., Barona, A., Ríos, F. J., Arreguy, A., Munguira, M., Peñas, J., Sanz, J. L. (2000) Application of biofiltration to the degradation of hydrogen sulfide in gas effluents, Biodegradation 11:423.

Engesser, K.-H., Plaggemeier, T. (2000) Microbiological aspects of biological waste gas purification, in: Biotechnology, $2^{\text {nd }}$ edition, Volume 11c. Environmental Processes III, Solid waste and waste gas treatment, preparation of drinking water, J. Klein, J., and J. Winter, eds., Wiley-VCH, Weinheim, pp. 275-302.

Gabriel, D., Deshusses, M. A. (2003) Retrofitting existing chemical scrubbers to biotrickling filters for $\mathrm{H}_{2} \mathrm{~S}$ emission control, Proc. Natl. Acad. Sci. U. S. A. 100:6308.

Goodwin, J. P., Amenta, S. A., Delo, R. C., Del Vecchio, M., Pinnette, J. R., Pytlar, T. S. (2000) Odor control advances at cocomposting facility, Biocycle January 2000:68.

Hartikainen, T., Ruuskanen, J., Vanhatalo, M., Martikainen, P. J. (1996) Removal of ammonia from air by a peat biofilter, Environ. Technol. 17:45.

Heller, W., Schwager, H. (1996) Luftreinigung durch Kompost-Biofiltration, Agrarforschung 3:520.

Huang, C. P., Chung, Y. C., Hsu, B. M. (1996) Hydrogen sulfide removal by immobilized autotrophic and heterotrophic bacteria in the bioreactors, Biotechnology Techniques 10:595.

Ibrahim, M. A., Mizuno, H., Yasuda, Y., Fukunaga, K., Nakao, K. (2001) Removal of mixtures of acetaldehyde and propionaldehyde from waste gas in packed column with immobilized activated sludge gel beads, Biochem. Eng. J. 8:9.

Jones, K., Martinez, A., Rizwan, M., Boswell, J. (2003) Evaluation of sulfur toxicity and media capacity for $\mathrm{H}_{2} \mathrm{~S}$ removal in biofilters packed with both natural and commercial media, in: Proceedings of the $96^{\text {th }}$ annual Air \& Waste Management Association Conference, June 22-26, San Diego, CA.

Joshi, J. A., Hogan, J. A., Cowan, R. M., Strom, P. F., Finstein, M. S. (2000) Biological removal of gaseous ammonia in biofilters: space travel and earth-based applications, J. Air Waste Manage. Assoc. 50:1647.

Kalingan, A. E., Liao, C. M., Chen, J. W., Chen, S. C. (2004) Microbial degradation of livestockgenerated ammonia using biofilters at typical ambient temperatures, J. Environ. Sci. Health Part B-Pestic. Contam. Agric. Wastes 39:85.

Kasakura, T., Tatsukawa, K. (1995) On the scent of a good idea for odour removal, Water Quality International 2:24.

Kennes, C., Veiga, M.C. (2001) Bioreactors for Waste Gas Treatment, Kluwer Academic Publishers, Dordrecht

Kiared, K., Wu, G., Beerli, M., Rothenbühler, M., Heitz, M. (1997) Application of biofiltration to the control of VOC emissions, Environ. Technol. 18:55.

Kim, N. J., Hirai, M., Shoda, M. (1998) Comparison of organic and inorganic carriers in removal of hydrogen sulfide in biofilters, Environ. Technol. 19:1233.

Kim, H., Xie, Q., Kim, Y. J., Chung, J. S. (2002) Biofiltration of ammonia gas with sponge cubes coated with mixtures of activated carbon and zeolite, Environ. Technol. 23:839.

Kirchner, K., Hauk, G., Rehm, H. J. (1987) Exhaust gas purification using immobilized monocultures (biocatalysts), Appl. Microbiol. Biotechnol. 26:579.

Kirchner, K., Gossen, C. A., Rehm, H. J. (1991) Purification of exhaust air containing organic pollutants in a trickle-bed bioreactor, Appl. Microbiol. Biotechnol. 35:396. 
Kosteltz, A. M., Finkelstein, A., Sears, G. (1996) What are the 'real opportunities' in biological gas cleaning for North America?, in: Proceedings of the 89th Annual Meeting \& Exhibition of Air \& Waste Management Association, A\&WMA, Pittsburgh, PA; 96-RA87B.02.

Lacoste, F., Bosque, F., Brenne, E. (1996) Monitoring atmospheric emissions from industrial colza trituration plants, Oleagineux Corps Gras Lipides 3:369.

Liang, Y. K., Quan, X., Chen, J. W., Chung, J. S., Sung, J. Y., Chen, S., Xue, D. M., Zhao, Y. Z. (2000) Long-term results of ammonia removal and transformation by biofiltration, J. Hazard. Mater. 80:259.

Luo, J. (2001) A pilot-scale study on biofilters for controlling animal rendering process odours, Wat. Sci. Technol. 44:277.

Mohseni, M., Allen, D. G. (1999) Transient performance of biofilters treating mixtures of hydrophilic and hydrophobic volatile organic compounds, J. Air Waste Manage. Assoc. 49:1434.

Mohseni, M., Allen, D. G. (2000) Biofiltration of mixtures of hydrophilic and hydrophobic volatile organic compounds", Chem. Eng. Sci. 55:1545.

Oberthür, R., Vossen, F. (2001) Intrinsic odour emission from rendering and the odour history of a rendering plant, in: Proceedings of the 1st IWA International Conference on Odour and VOCs: Measurement, Regulation and Control Techniques, The University of NSW, Sydney, Australia, 25 - 29th March, pp. 131-138.

Otten, L., Afzal, M. T., Mainville, D. M. (2004) Biofiltration of odours: laboratory studies using butyric acid, Adv. Environ. Res. 8:397.

Park, S.-J., Hirai, M., Shoda, M. (1993) Treatment of exhaust gases from a night soil treatment plant by a combined deodorization system of activated carbon fabric reactor and peat biofilter inoculated with Thiobacillus thioparus DW44, J. Ferment. Bioeng. 76:423.

Park, S.-J., Nam, S.-I., Choi, E.-S. (2001) Removal of odor emitted from composting facilities using a porous ceramic biofilter, Wat. Sci. Technol. 44:301.

Park, D. H., Cha, J. M., Ryu, H. W., Lee, G. W., Yu, E. Y., Rhee, J. I., Park, J. J., Kim, S. W., Lee, I. W., Joe, Y. I., Ryu, Y. W., Hur, B. K., Park, J. K., Park, K. (2002) Hydrogen sulfide removal utilizing immobilized Thiobacillus sp IW with Ca-alginate bead, Biochem. Eng. J. 11:167.

Peixoto, J., Mota, M. (1997) Volatile organic compounds evaporation chamber for the simulation of gas effluents in laboratory research, Biotechnology Techniques 11:1.

Peixoto, J., Mota, M. (1998) Biodegradation of toluene in a trickling filter, Bioproc. Eng. 19:393.

Perry, R. H., Green, D. (1984) Perry's Chemical Engineers' Handbook, $6^{\text {th }}$ ed., McGraw-Hill International Editions. Chemical Engineering Series, New York, 2234 p.

Rafson, H. J. (1998) Odor and VOC Control Handbook . McGraw-Hill, New York.

Regan, J. M., Harrington, G. W., Noguera, D. R. (2002) Ammonia- and nitrite-oxidizing bacterial communities in a pilot-scale chloraminated drinking water distribution system, Appl. Environ. Microbiol. 68:73.

Reij, M. W., Keurentjes, J. T. F., Hartmans, S. (1998) Membrane bioreactors for waste gas treatment, J. Biotechnol. 59:155.

Ritchie, B. J., Hill, G. A. (1995) Biodegradation of phenol polluted air using an external loop airlift bioreactor, J. Chem. Technol. Biotechnol. 62:339.

Rittmann, B. E., Schwarz, A. O., Sáez P. B. (2000) Biofilms applied to hazardous waste treatment, in: Biofilms II, J. Bryers, ed., John Wiley \& Sons, Inc., New York, pp. 207-234.

Ruokojärvi, A., Ruuskanen, J., Martikainen, P. J., Olkkonen, M. (2001) Oxidation of gas mixtures containing dimethyl sulfide, hydrogen sulfide, and methanethiol using a two-stage biotrickling filter, J. Air Waste Manage. Assoc. 51:11.

Schramm, A., De Beer, D., Gieseke, A., Amann, R. (2000) Microenvironments and distribution of nitrifying bacteria in a membrane-bound biofilm, Environ. Microbiol. 2:680.

Sercu, B., Demeestere, K., Baillieul, H., Verstraete, W., Van Langenhove, H. (2005a), Degradation of isobutanal at high loading rates in a compost biofilter, J. Air Waste Manage. Assoc. 55:1217.

Sercu, B., Núñez, D., Van Langenhove, H., Aroca, G., Verstraete, W. (2005b), Operational and microbiological aspects of a two-stage biotrickling filter removing hydrogen sulfide and dimethyl sulfide, Biotechnol. Bioeng. 90:259. 
Sheridan, B. A., Curran, T. P., Dodd, V. A. (2003) Biofiltration of n-butyric acid for the control of odour, Bioresource Technol. 89:199.

Shoda, M. (1991) Methods for the biological treatment of exhaust gases, in: Biological Degradation of Wastes, A. M. Martin, ed., Elsevier Science Publishers, New York, pp. 31-46.

SIS, (2000) Scientific Instruments Services: adsorbent resins, general listing and description of seven resins; http://www.sisweb.com/index/referenc/resin2.htm

Smet, E. (1995) Evaluatie werking biofilter - De Kleijn (Maaseik), Unpublished Report, Ghent University.

Smet, E., Chasaya, G., Van Langenhove, H., and Verstraete, W. (1996a) The effect of inoculation and the type of carrier material used on the biofiltration of methyl sulphides, Appl. Microbiol. Biotechnol. 45:293.

Smet, E., Lens, P., and Van Langenhove, H. (1998) Treatment of waste gases contaminated with odorous sulphur compounds, Crit. Rev. Environ. Sci. Technol. 28:89.

Smet, E., Van Langenhove, H., and Verstraete, W. (1996b) Long-term stability of a biofilter treating dimethyl sulphide, Appl. Microbiol. Biotechnol. 46:191.

Smet, E., Van Langenhove, H., Maes, K. (2000) Abatement of high concentrated ammonia loaded waste gases in compost biofilters, Water Air Soil Poll. 119:177.

Smet, E., Van Langenhove, H., and Verstraete, W. (1997) Isobutyraldehyde as a competitor of the dimethyl sulfide degrading activity in biofilters, Biodegradation 8:53.

Smits, M. C. J., Hoek, A. P., Osinga, B., Ottengraf, S. P. P., and Wijngaard, M. H. (1995) Removal of ammonia with odour from composting facility waste gas with a bio-trickling filter, Meded. Fac. Landbouww. Gent 60:2313.

Tang, H.-M., Hwang, S.-J., and Hwang, S.-C. (1996) Waste gas treatment in biofilters, J. Air Waste Manage. Assoc. 46:349.

Terasawa, M., Hirai, M., and Kubota, H. (1986) Soil deodorization systems, Biocycle 27:28.

Van Elst, T., and Van Langenhove, H. (2001) Case study: odour emission at a vegetable oil plant in France, in: Proceedings of the $1^{\text {st }}$ IWA International Conference on Odour and VOCs: Measurement, Regulation and Control Techniques, The University of NSW, Sydney, Australia, 25-29 March, pp. 91-398.

Van Groenestijn, J. W., and Hesselink, P. G. M. (1993) Biotechniques for air pollution control, Biodegradation 4:283.

Van Langenhove, H., Bendinger, B., Oberthür, R., and Schamp, W. (1992) Organic sulfur compounds: persistant odourants in the biological treatment of complex waste gases, in: Biotechniques for Air Pollution Abatement and Odour Control Policies, A. J. Dragt, and J. van Dam, Eds., Elsevier, Amsterdam, pp. 309-313.

Van Langenhove, H., Cornelis, C., Schamp, N., and Wuyts, E. (1989a) Biofiltration in a vegetables processing industry, Meded. Fac. Landbouww. Gent 54:1471.

Van Langenhove, H., Lootens, A., and Schamp, N. (1988) Elimination of ammonia from pigsty ventilation air by wood bark biofiltration, Meded. Fac. Landbouww. Gent 53:1963.

Van Langenhove, H., Lootens, A., and Schamp, N. (1989b) Inhibitory effects of $\mathrm{SO}_{2}$ on biofiltration of aldehydes, Water Air Soil Poll. 47:81.

Van Lith, C., Leson, G., and Michelsen, R. (1997) Evaluating design options for biofilters, J. Air Waste Manage. Assoc. 47:37.

VDI (1996) Emissionsminderung, Anlagen zur Verwertung und Beseitigung von Tierkörperteilen und tierischen Erzeugnissen, Düsseldorf, Verein Deutscher Ingenieure

Wada, A., Shoda, M., Kubota, H., Kobayashi, T., Katayama-Fujimura, J., and Kuraishi, H. (1986) Characteristics of $\mathrm{H}_{2} \mathrm{~S}$ oxidizing bacteria inhabiting a peat biofilter, J. Ferment. Technol. 64: 161 .

Wani, A. H., Lau, A. K., and Branion, R. M. R. (1999) Biofiltration control of pulping odors hydrogen sulfide: performance, macrokinetics and coexistence effects of organo-sulfur species, J. Chem. Technol. Biotechnol. 74:9.

Warren, J., Loerh, C., and Fellow A. S. C. E. (1997) Biofiltration: fundamentals, design and operation principles and applications, J. Environ. Eng. 123:538.

Waweru, M., Herrygers, V., Van Langenhove, W., and Verstraete, W. (2000) Process engineering of biological waste gas purification, in: Biotechnology, $2^{\text {nd }}$ edition, Volume 11c. Environmental Pro- 
cesses III, Solid Waste and Waste Gas Treatment, Preparation of Drinking Water, J. Klein, and J. Winter, eds., Wiley-VCH, Weinheim, pp. 260-273.

Weast, R. C., Astle, M. J., and Beyer, W. H. (1984) CRC. Handbook of Chemistry and Physics, 64 ${ }^{\text {th }}$ ed., CRC Press, Inc., Boca Raton, Florida, 2303 p.

Weckhuysen, B., Vriens, L., and Verachtert, H. (1993) The effect of nutrient supplementation on the biofiltration removal of butanal in contaminated air, Appl. Microbiol. Biotechnol. 39:395.

Weckhuysen, B., Vriens, L., and Verachtert, H. (1994) Biotreatment of ammonia-containing and butanal-containing waste gases, Appl. Microbiol. Biotechnol. 42:147.

Williams, T. O., 1995, Odors and VOC emissions control methods, Biocycle 36:49.

Wu, L., Loo, Y.-Y., and Koe, L. C. C. (2001) A pilot study of a biotricking filter for the treatment of odorous sewage air, Wat. Sci. Technol. 44:295.

Yang, Y., and Allen, E. R. (1994a) Biofiltration control of hydrogen sulfide 1. Design and operational parameters, J. Air Waste Manage. Assoc. 44:863.

Yang, Y., and Allen, E. R. (1994b) Biofiltration control of hydrogen sulfide 2. Kinetics, biofilter performance, and maintenance, J. Air Waste Manage. Assoc. 44:1315.

Yang, Y., Togna, A. P., and Skladany, G. (1994) Treatment of $\mathrm{CS}_{2}$ and $\mathrm{H}_{2} \mathrm{~S}$ vapors by biofiltration, in: Proceedings of the $49^{\text {th }}$ Purdue Industrial Waste Conference, Purdue University, pp. 449-456.

Yani, M., Hiral, M., and Shoda, M. (1998) Ammonia gas removal characteristics using biofilter with activated carbon fiber as a carrier, Environ. Technol. 19:709.

Zhang, L., Hirai, M., and Shoda, M. (1991) Removal characteristics of dimethyl sulfide, methanethiol and hydrogen sulfide by Hyphomicrobium sp. I55 isolated from peat biofilter, J. Ferment. Bioeng. 72:392. 